\title{
Global Change and Forest Disturbances in the Mediterranean Basin: Breakthroughs, Knowledge Gaps, and Recommendations
}

\author{
Josep Peñuelas ${ }^{1,2}$ (D) and Jordi Sardans $1,2, *(\mathbb{D})$ \\ 1 CSIC, Global Ecology Unit CREAF-CSIC-UAB, 08913 Bellaterra, Spain; josep.penuelas@uab.cat \\ 2 CREAF, 08193 Cerdanyola del Vallès, Spain \\ * Correspondence: j.sardans@creaf.uab.cat
}

Citation: Peñuelas, J.; Sardans, J. Global Change and Forest

Disturbances in the Mediterranean Basin: Breakthroughs, Knowledge Gaps, and Recommendations. Forests 2021, 12, 603. https://doi.org/ 10.3390/f12050603

Academic Editor: Eustaquio Gil-Pelegrín

Received: 29 March 2021

Accepted: 7 May 2021

Published: 11 May 2021

Publisher's Note: MDPI stays neutral with regard to jurisdictional claims in published maps and institutional affiliations.

Copyright: (c) 2021 by the authors. Licensee MDPI, Basel, Switzerland. This article is an open access article distributed under the terms and conditions of the Creative Commons Attribution (CC BY) license (https:// creativecommons.org/licenses/by/ $4.0 /)$.
Abstract: Forest ecosystems in the Mediterranean Basin are mostly situated in the north of the Basin (mesic). In the most southern and dry areas, the forest can only exist where topography and/or altitude favor a sufficient availability of water to sustain forest biomass. We have conducted a thorough review of recent literature (2000-2021) that clearly indicates large direct and indirect impacts of increasing drought conditions on the forests of the Mediterranean Basin, their changes in surface and distribution areas, and the main impacts they have suffered. We have focused on the main trends that emerge from the current literature and have highlighted the main threatens and management solution for the maintenance of these forests. The results clearly indicate large direct and indirect impacts of increasing drought conditions on the forests of the Mediterranean Basin. These increasing drought conditions together with over-exploitation, pest expansion, fire and soil degradation, are synergistically driving to forest regression and dieback in several areas of this Mediterranean Basin. These environmental changes have triggered responses in tree morphology, physiology, growth, reproduction, and mortality. We identified at least seven causes of the changes in the last three decades that have led to the current situation and that can provide clues for projecting the future of these forests: (i) The direct effect of increased aridity due to more frequent and prolonged droughts, which has driven Mediterranean forest communities to the limit of their capacity to respond to drought and escape to wetter sites, (ii) the indirect effects of drought, mainly by the spread of pests and fires, (iii) the direct and indirect effects of anthropogenic activity associated with general environmental degradation, including soil degradation and the impacts of fire, species invasion and pollution, (iv) human pressure and intense management of water resources, (v) agricultural land abandonment in the northern Mediterranean Basin without adequate management of new forests, (vi) very high pressure on forested areas of northern Africa coupled with the demographic enhancement, the expansion of crops and higher livestock pressure, and the more intense and overexploitation of water resources uses on the remaining forested areas, and (vii) scarcity and inequality of human management and policies, depending on the national and/or regional governments and agencies, being unable to counteract the previous changes. We identified appropriate measures of management intervention, using the most adequate techniques and processes to counteract these impacts and thus to conserve the health, service capacity, and biodiversity of Mediterranean forests. Future policies should, moreover, promote research to improve our knowledge of the mechanisms of, and the effects on, nutrient and carbon plant-soil status concurrent with the impacts of aridity and leaching due to the effects of current changes. Finally, we acknowledge the difficulty to obtain an accurate quantification of the impacts of increasing aridity rise that warrants an urgent investment in more focused research to further develop future tools in order to counteract the negative effects of climate change on Mediterranean forests.

Keywords: aridity; drought; forest pests; forest dieback; mediterranean; nutrients; pollution; soil; species invasion; warming 


\section{Background. Mediterranean Forest: A System Shaped by Water, Nutrient Limitations, and Human Management. The Mediterranean Basin Case}

Five coastal regions of the continents between latitudes of 34 and $45^{\circ}$ in both hemispheres have Mediterranean climates: Mediterranean Basin, California, central Chile, the Cape region of South Africa and southwestern and southern Australia [1,2]. This Mediterranean climate has typically been associated with wet and cold winters and dry and hot summers, but with high variability, mainly in the intensity of the drier periods that increases from high to low latitudes in these areas [1,2]. The Mediterranean Basin has a large range of ecosystems, socioeconomic conditions, governmental policies, and long-term human influence [3,4]. The Mediterranean Basin is a global hotspot of biological diversity and the most diverse biome in Europe. Models, however, have projected a loss of area of about $11-25 \%$ by the end of this century [5,6], mainly due to the advance of desertification [6]. However, Alessandri et al. (2014) [7] using 25 different General Circulation Models projected that the Mediterranean climate could also be expanded at the end of the 21th century towards north-east by $740,000 \mathrm{~km}^{2}$, a $19 \pm 1 \%$ of the current Mediterranean are in the Mediterranean Basin. The current legacy of Mediterranean forests has nevertheless been modulated by historical socioeconomic pressures, leading to several unsustainable forest practices and frequently to the neglect by human society of forested land by human society [8]. The combination of climate change, anthropogenic disturbance (overexploitation of forest resources, human-induced fires, and deforestation) and other aspects of global change (particularly inappropriate land uses and pollution) will continue to affect Mediterranean forest vegetation [9]. Forests are, however, estimated to currently cover about $10 \%$ of the total land surface of the Mediterranean Basin [10]. This means that the total Mediterranean Basin has more than 25 million ha of forest plus 50 million ha of other wooded lands mainly associated to crop abandonment [11]. Between 2010 and 2015, forests in the Mediterranean Basin have increased their cover by $2 \%$, but the level of forest degradation, and the vulnerabilities to climate change, population expansion, wildfires and aridity have also increased [11].

The Mediterranean Basin is especially sensitive to climate change due to the nature of transition between arid and temperate regions [12]. The increase in aridity in the basin has been widely demonstrated throughout the last decades [13-16]. Aridity is even projected to increase in the future under a projected $3-4{ }^{\circ} \mathrm{C}$ increase in temperature and $20 \%$ decrease in rainfall in forested areas $[5,10,17,18]$. Recent data indicate a temperature increase in the last century of about $0.85^{\circ} \mathrm{C}$ globally and $1.3^{\circ} \mathrm{C}$ in the Mediterranean area compared to temperatures for 1880-1920 [19]. Apart from the lower water content during most of the year, Mediterranean soils often suffer nutrient deficiencies, especially of nitrogen $(\mathrm{N})$ and phosphorus (P) $[18,20-23]$. This low fertility is especially critical in forests due to their higher demands for water and nutrients $[5,18]$. The effects of higher $\mathrm{CO}_{2}$ levels are also increasingly affecting foliar composition and $\mathrm{P}$ and $\mathrm{N}$ contents, further decreasing nutrient availability [24]. Although, the Mediterranean forest is still a global sink of carbon [10]. In 2005, the Mediterranean Basin forest accumulated $4.6 \mathrm{Mt} \mathrm{y}^{-1}$ and this value can change between 3.3 to $5.97 \mathrm{Mt} \mathrm{y}^{-1}$ in 2050 depending on the future socioeconomic scenarios [10].

The increase in forested area in the last 100-150 years is mainly due to forest regeneration in rural areas following continuous abandonment, as observed in several Mediterranean countries, and more recently it is also due to the European Common Agriculture Policy (as in Spain) [18,25]. Remote-sensing studies focusing on the overall Mediterranean Basin region have more recently indicated that the area of forests in the Mediterranean region has remained stable or slowly increase in the last few decades (see the "Depopulation and abandonment of rural areas" section below). A stable or increasing forest area, as defined by the FAO, though, tells us nothing about forest degradation [10]. To all these circumstances, we must add in Mediterranean forested areas the long-term influence of certain extensive use of forests to obtain several products such as food, cork, wood, etc. at once $[18,25]$. For example, the dehesas are agroforestry systems that have been managed in the long-term by humans endeavoring several activities such as raising pigs, bulls, and 
goats or growing cereals that coexist with an open forest dominated frequently by evergreen oaks, mainly Quercus robur L., Quercus pubescens Willd., Quercus ilex L., and Quercus rotundifolia Lam. $[10,18]$. These systems mostly occupy locations that without human intervention would mostly become evergreen holm oak forests, which would increase the risk of great and frequent fires [10]. These areas occupy $17.7 \%$ of the Mediterranean region [10] and are currently threatened by human abandonment and agricultural intensification which drives them to an uncertain future [10].

The high plant diversity that characterizes Mediterranean ecosystems is associated with the success of coexisting species in avoiding competition for soil resources by differential exploitation of space (soil layers) and time (yearly and daily) [18]. The long-term evolutionary adaptation of Mediterranean plants to drought thus allows them to cope with moderate increases in drought without excessive losses of production and survival in some species [18,26-30]. For example, increasing the allocation of resources to roots providing a deep root system helps capture soil nutrient and water from deep soil layers and protect against soil erosion [18]. This together with high translocation and resorption of foliar nutrients, large contents of recalcitrant compounds, and high conservative and efficient use of soil resources provide Mediterranean plants a high resistance to drought stress [18]. The current increase in aridity and its interactions with other disturbances such as fire, expansion of pest ranges, and plant invasion, however, may decrease this capacity for resistance, and may degrade soils, as it is already occurring in some areas of the southern Iberian Peninsula, France, and Italy [18,27,30-35].

This study thus aimed to (i) identify the current status of the diverse human and natural disturbances in Mediterranean forests over recent decades, (ii) identify the main causes of the changes in these forested areas responsible for the current situation, which can provide clues for projecting a future perspective for forested areas in the Mediterranean Basin, (iii) propose actions that could help improve the survival of the forest biome in the Mediterranean Basin, and (iv) identify obscure issues from all levels that help advance our knowledge for obtaining a global overview of the present and future evolution of this biome. The sites with observational/experimental data finally used in this study are highlighted in Figure 1.

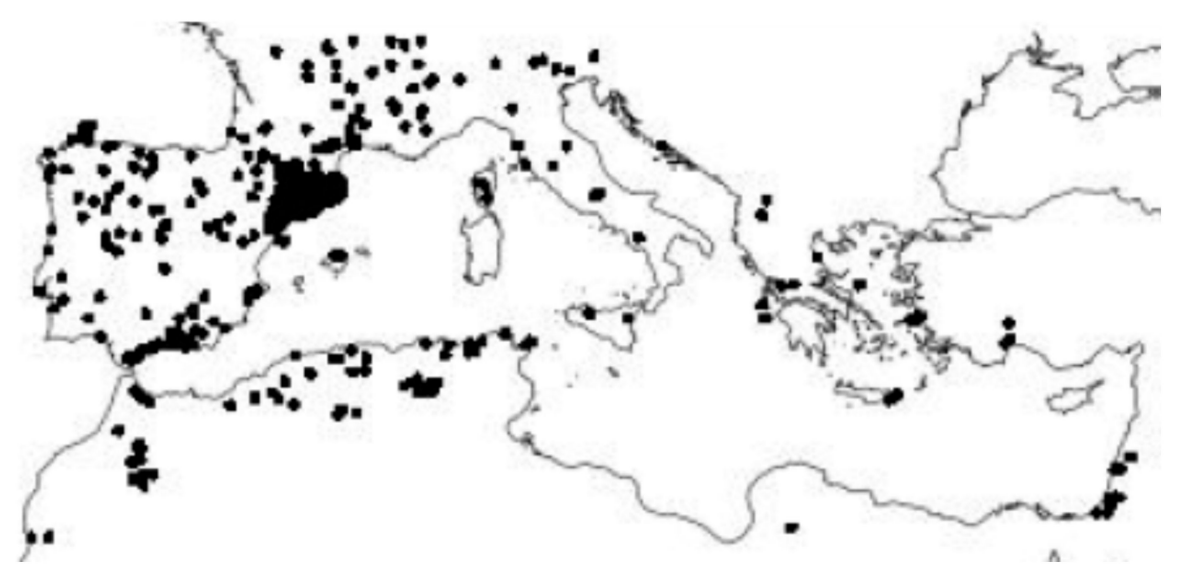

Figure 1. Sites with observational/experimental data used in this study.

\section{Several Concurrent Risks}

\subsection{Present and Future Aridity: The Larger Threat}

The current increase in aridity in the Mediterranean Basin in recent decades is associated with higher temperatures in southern Europe and northern Africa [35-37]. Most models project larger increases in aridity in the Mediterranean Basin [37-40] and a shift of current arid conditions towards northern latitudes [5]. Based on various scenarios of future climate projection, Barredo et al. (2016) [5] reported that the current climatic area of the basin would shift to other areas by the end of the 21st century and that the current area 
would decrease by $15-23 \%$. Central and southern areas of the Iberian Peninsula, southern Italian Peninsula, some Mediterranean islands, central Turkey, North Africa, and southeastern Greece are the most affected areas, with larger shifts in the area of Mediterranean climate towards hotter and drier climates. Extreme precipitation and a general decrease in total precipitation and increase in temperature, however, are also expected [41,42]. A general increase in aridity, coupled with stronger and potentially destructive storms causing flood damage and extreme heatwaves, are thus possible [41-43]. These changes have already had several impacts on plant-soil systems in Mediterranean forested areas $[18,44,45]$ and are expected to continue in the near future [18].

For example, a long-term (20 years) climatic manipulation in a holm oak (Quercus ilex) forest has produced a continuously lower availability of soil water similar to that projected for the near future and has demonstrated that the capacity of the trees to adapt to this level of drought is higher than previously expected [46]. Most species of tall evergreen shrubs, however, have increased in coverage and biomass more than Q. ilex $[47,48]$, and the forest structure can be transformed into a shrubland structure under more frequent intense heatwaves and droughts $[10,18,46,49]$.

To complete this scenario, we must consider that the Mediterranean climate has frequent torrential rains [50] that are projected to increase [51] and thus produce larger nutrient losses in the near future. In this context, the rise in drought periods together with more frequent extreme rain events can exert a strong impact on Mediterranean soil C:N:P ratios due to the different cycling and solubility/volatilization of these three elements [18]. This can in turn also have asymmetrical effects favoring more some species than others [18]. A cascade of feedback effects among increased aridity, more frequent torrential rains, more intense and frequent fires, and changes in land use have thus exceeded the capacity of Mediterranean plants to cope with drought and other stresses [52,53] (Figure 2). For example, several areas of central and southern Spain suffer from advanced stages of degradation and losses of biomass and soil, ultimately leading to desertification $[18,54,55]$. This scenario is not favorable for maintaining the current area of forests in the basin and thus for conserving their current structures, species compositions, ranges and diversities [18,56-58]. In fact, forests have clearly moved towards higher altitudes of the basin in the last few decades $[59,60]$.

Several studies have consistently reported that annual growth and seed production in Mediterranean forests in recent decades are strongly correlated with annual drought intensity [61,62]. Warmer and drier conditions linked to increases in Atlantic multidecadal oscillations (AMO) are associated with the increase in post-1990 defoliation in the forests of Spain [63]. Experimental, observational, and metadata studies have clearly indicated that the decreases (dieback, defoliation, and lower growth) in Mediterranean oaks (Quercus spp.) and pines (Pinus spp.) in southern Europe are mainly due to more frequent drought, often interacting with higher temperatures (higher water demand) and pathogenic attack [64-70], all of which are associated with further decreases in nutrient-cycling rates, changes to soil trophic-web structure, and lower soil fertility [71,72]. 


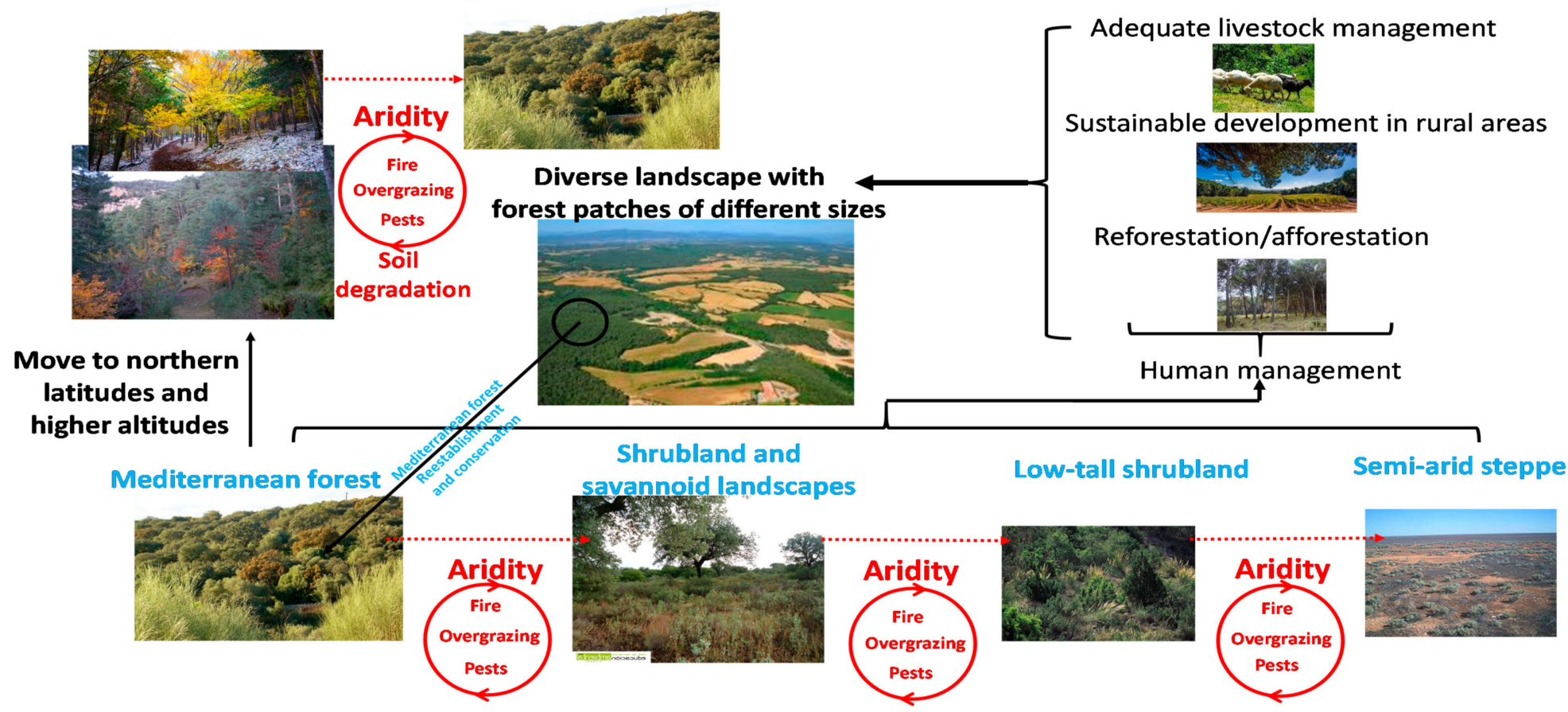

Soil degradation

Soil degradation

Soil degradation

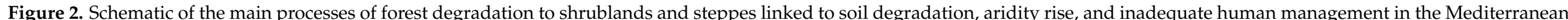
Basin. 
Studies have also widely observed that tree dieback under drought conditions is associated with a depletion of reserves of nonstructural carbohydrates [73] and with a general increase in tree dormancy [74] and decrease in gross primary production (GPP) [75]. Mediterranean trees in their current distributions are thus frequently at the limit of their capacity of positive net primary production, so a further increase in aridity would be catastrophic [76-78]. The suitable period of growth of $Q$. ilex forests has been advanced by approximately 10 days by advancing the onset of spring by winter warming, but an early cessation of growth in spring and summer by approximately 26 days has reduced tree production and growth capacity [76]. This limiting situation has even been detected in the most xeric tree in the Mediterranean Basin, Pinus halepensis, whose populations in the semi-arid limit of its distribution in southern Europe have already been strongly affected by drought in the last two decades $[77,78]$. The overall Mediterranean domain is projected to shift to North in the coming decades [5,79].

Several Mediterranean forested areas are on steep slopes and thus frequently have shallow soils, so they are more sensitive to drought as observed in climate models in scenarios of atmospheric $\mathrm{CO}_{2}$ concentrations affected, with reductions in growth during and after the severe droughts of the 1990s and rising [80]. Therefore, forests tend to be replaced with shrubland and even steppe vegetation as projected in climate models for scenarios of rising atmospheric $\mathrm{CO}_{2}$ concentrations [81] (Figure 2). A recent study with satellite data found that an expansion of slow-growing evergreen hardwood Mediterranean species, forest dieback and defoliation of mainly non-Mediterranean species, and diseases and pests could be observed along the gradient between temperate wet and Mediterranean climates in western Europe [82]. Even replanting with the most drought-resistant Mediterranean tree species in desert areas of southeastern Spain has been negatively affected by the increasing frequency and intensity of drought, with more defoliation and decreased growth [83].

Some studies have observed how drought can limit the potential positive response to rising atmospheric $\mathrm{CO}_{2}$ concentrations [84]. The expansion of shrublands at the expense of forests is thus expected from the interaction of more intense and extreme recurrence of droughts associated with warming and large fires [85-88]. Interestingly though, the increasing patchiness of forests, however, can increase the capacity of forests to resist future drought. Flores-Renteria et al. (2015) [89] reported that decreasing the fragment size of holm oak forests in central and southern Spain improved resistance to further drought by improving local environmental conditions, with higher water-use efficiency and availabilities of soil water and nutrients.

The situation of Mediterranean forest associated to global warming is especially critical in the North Africa Mediterranean forest. The impact of drought-aridity rise in the last few years of forest dieback in North Africa has been especially intense from 1970s-1980s and up to the current days [90-98]. This process is especially intense in several areas where the overgrazing pressure, the expansion of crops, and the urbanization, together with wood exploitation have continuously risen [98-102]. These strong and fast multiple effects of human related activities have proven to favor the most stress-tolerant species such as Quercus suber and be detrimental for species with higher water needs such as Cedrus atlantica in areas where they coexist [100].

\subsubsection{Drought Is Currently Shaping the Structure of Mediterranean Forests}

An increase in drought, however, may also have different effects in different forest Mediterranean species and communities. Mediterranean plants have developed various morphological and physiological strategies to adapt to drought [36], but the largest trees in a community are frequently more sensitive and less resistant and resilient to increases in aridity [36,103]. Sperlich et al. (2015) [104] observed that semi-deciduous and deciduous species responded differently from evergreen species to severe summer drought. The impact of drought on defoliation and dieback can asymmetrically affect individual trees based on size, even in the same species, shorter trees are more resistant and resilient to increases in drought than taller trees, both in intra- and interspecific comparisons [105]. Tall 
shrub species defoliate less than dominant canopy trees under more intense drought, so tall shrubs tend to produce more leaves in the upper canopy levels in a clear step towards replacing forests with shrubland [106,107]. The effects of drought across current environmental gradients of aridity may differ more between current xeric sites than mesic sites. Pasho et al. (2012) [108] reported that a specific decrease in annual precipitation was responsible for canopy defoliation in most xeric forests, dominated mainly by species such as $P$. halepensis Mill. and Q. ilex, whereas the worsened annual water balance was responsible for defoliation in more mesic forests, dominated by species such as P. sylvestris L., P. nigra Arnold or Abies alba Mill. Pasho et al. (2011) [109] found that the growth of species at xeric sites responded to the amount of spring and summer precipitation, whereas the growth of species at mesic sites responded more directly to the amount of summer precipitation only.

Most studies have nevertheless found that the effects of drought on the fitness of various species of Mediterranean forest trees were much more detrimental to mesic than to more xeric species [110-112]. Genera that have evolved under Mediterranean climatic conditions, mostly shrubs, however, were more damaged by the severe drought in 1994 in Spanish woodland areas than pre-Mediterranean species, mostly trees, that evolved earlier such as Pinus sp, Quercus sp. or Olea europea L. [49]. Contrasting results, though, have also been reported [113]. These asymmetrical effects are even more evident when comparing the Mediterranean with temperate and/or boreal tree species coexisting in mountainous areas within Mediterranean latitudes where the Mediterranean species are expanding to sites previously occupied by wet-temperate forest species [114].

Tall shrubs such as Phillyrea sp. have a higher capacity than trees to adapt and resist intensive droughts $[115,116]$ and have a higher capacity than sympatric trees to maintain their foliage and concentrations of nonstructural carbohydrates after droughts [116]. Experimental and observational studies have clearly demonstrated a scenario of gradual replacement in communities from dominance by trees to dominance by tall shrubs $[115,116]$.

\subsubsection{Grazing Pressure under Drought Enhancement}

Disturbance by livestock and over-exploitation have frequently increased, thus aggravating the negative effect of the reduction in natural precipitation $[117,118]$. These disturbances have been especially observed in savannoid woodlands and dehesas, the agroforestry human managed ecosystem where the Mediterranean evergreen genus Quercus is dominant [54,119]. This savonnoid system combines livestock exploitation with pigs and bovine with grain crops mainly located in the central and southern Iberian and Italian Peninsulas $[54,119]$. These systems are currently frequently accompanied by encroachment that has even worsened the tree status by increasing the competition for soil water between deep-rooted shrubs and trees [120].

However, the livestock pressure is decreasing very fast in large parts of the northern Mediterranean basin, to such an extent, that herbivory has fallen to levels unnaturally low [119]. This is leading to dense pioneer forests going hand in hand with massive loss of botanical diversity of small light demanding species that need levels of grazing [119]. The increasing frequency of annual extreme summer droughts in recent decades has been directly monitored at the plot level $[121,122]$ or by multitemporal imagery from satellites such as Sentinel-2 [123]. These studies have found that extreme droughts can have more detrimental effects on Mediterranean forests than a long-term constant increase in drought intensity [122], and that the increasing frequency of extreme droughts decreases resistance and resilience of forest ecosystems, exacerbating the recovery of Mediterranean forests [121].

2.1.3. Aridity and Warming: An Open Door for Pests. The Case of "La Seca" (Phytophthora cinnamomi Rands) and Insect Outbreaks

The increases in heatwaves, warming, and droughts have been associated with pathogens in Mediterranean forests, such as the pine processionary moth (Thaumetopoea pityocampa Schiff), which has been expanding even more to northern forests and that has 
been correlated with a reduction in the growth of pine trees in several pine forests in the Mediterranean Basin [124-126].

The aggressive Phytophthora fungi (mainly P. cinnamomi), widely known in the Iberian Peninsula as "La seca" [127], however, is causing the largest areas of mortality. Infestation by P. cinnamomi is currently the main direct cause of declines in Q. ilex and Q. suber forests in several areas of southern Europe [128], with a large capacity to kill these two species [129]. The increasing spread of this pathogen has been favored by warmer temperatures and increased aridity [130-134], making it very difficult to discern between drought, rise in temperature or P. cinnamomi as the main cause of Quercus forest decline [135]. This pathogen is expected to spread further with the projected warmer temperatures and increase in drought in Mediterranean and sub-Mediterranean areas of southern Europe, mainly in Quercus forests [134-137]. Recent satellite images and photointerpretation studies in locations of affected trees in southwestern Spain from 2001 to 2016 have identified spatial patterns consistent with the hypothesis that Phytophthora is the main cause of open oak forests (dehesas) defoliation and decline in the study areas that may also be influenced by increased drought [138]. Infestation by P. cinnamomi can interfere with and suppress the expression of tree genes involved in chemical defenses such as tannins [139], and the metabolomic shifts of trees affected by this pathogen are similar to those for drought [140]. The early stages of infestation by Phytophthora spp., however, are difficult to detect [140].

Many recent studies and experiments have provided more information about Phytophthora spp. infestation. The decline of Quercus forests caused by Phytophthora spp. is concurrent with losses in the biological activity and nutrient availability in the soil [136], with large impacts on the trophic web of soil invertebrates [141]. The deleterious effects of P. cinnamomi depends on site traits and species [142]. Quercus species in the Mediterranean Basin are generally more sensitive to this pathogen than are Pinus species, and the two most xeric Pinus species, $P$. halepensis and P. pinea L., are more sensitive than more mesic species such as P. nigra, P. pinaster Ait., and P. sylvestris [143-146]. The decline of P. pinaster in some areas of Spain has been mainly driven by drought and other biotic factors such as infestation by Viscum album L., and not by Phytophthora [144]. Moreira et al. (2018) [145] reported that the resistance of $Q$. suber and $Q$. faginea Lam. saplings to P. cinnamomi depended on different genotypic groups associated with a geographic origin and that $Q$. faginea saplings were generally more resistant than $Q$. suber saplings, suggesting that $Q$. faginea could be used as a rootstock for $Q$. suber reforestation. The common habit of planting plants such as wheat, oat, vetch or lupin among the trees in open Quercus woodland can accelerate the spread of P. cinnamomi, depending on the host species. Wheat and oats are not infested, but lupin can be infested, contributing to higher densities of zoospores and thus the expansion of this tree disease [146].

Insect outbreaks may also have strong impacts on the Mediterranean forest [147-150]. The interaction with aggravating biotic factors, such as insect attack, determines the tree's resistance to drought. Several studies have reported warming-arid periods related to high levels of defoliation by an insect attack [150-155]. Outbreaks produced by the gypsy moth (Lymantria dispar dispar) have been observed after dry-warm seasons in Pinus radiate and Castanea sativa forests in Spain [155]. A rise in the dieback associated to fungus has been observed to be related with the aridity rise in the last few decades [91,97,148,156-160]. Attacks by pathogenic fungi are especially intense in some forests of the North Africa Mediterranean range affecting intensely $Q$. ilex and Q. suber in Algeria mountains [156]. The Argania spinosa forests that are most able to resist dry conditions in the extreme arid limit with the Sahara Desert have been especially threatened by the continuous rise of warming [161,162]. In contrast, some forests in wetter sites such as Central Atlas have been more stable during the last decades [163].

\subsubsection{The Particular Case of Temperate and Boreal "Forest Islands"}

Mediterranean species are expanding into areas containing non-Mediterranean forest species $[88,114,144]$. Mediterranean forest species are more resilient to extreme and chronic 
droughts than species at wetter sites throughout the Mediterranean Basin [164-166]. This resilience is especially common in Mediterranean varieties of two typical non-Mediterranean species, Fagus sylvatica L. $[45,88,167,168]$ and P. sylvestris $[144,165,169-174]$, that occupy large areas of Mediterranean mountains and provide considerable forest ecosystem services in the landscape. Some recent studies have focused on the effects of current and past droughts on P. sylvestris in mountains in southern Europe, with clear and increasing symptoms of declining crowns and increased defoliation and mortality, mainly in stands at low altitudes [144,171-173].

Microclimatic conditions driven by topographic features allow the establishment of sub-Mediterranean, wet temperate, and even boreal forests in the Mediterranean biome, particularly in southern Europe [175]. The effects of drought have been largely detrimental to the forest populations of those species in the border of its species distribution area. There is an increased mortality and a decreased recruitment [169], e.g., in P. sylvestris and P. uncinata Ramond in Iberian areas [176], decreases in forest density in F. sylvatica forests in the Iberian Peninsula, southern France, and Italy $[114,175]$. The increase in aridity is the main but not the only cause of the decline and increased mortality of these communities. Other variables sometimes associated with aridity, such as the amount of atmospheric ozone, are also affecting these non-Mediterranean forests at high altitudes [176]. The dieback and substitution of temperate/boreal species by Mediterranean forest species is even faster where browsing pressure by ungulates is high, as in Sierra Nevada mountains (South Spain), where ungulates prefer to feed on P. sylvestris than P. pinaster saplings [177].

\subsection{Species Invasion}

Forests are generally the least invaded habitats globally [178], particularly in Europe and the Mediterranean Basin, where forests are currently not especially affected by species invasion $[10,179]$. Peri-urban forests, however, are the most vulnerable to invasion due to the presence and activity of humans that apply pressure for dispersing invasive species [180]. Human perturbation of open ecological spaces allows new species to invade while maintaining high resource availability [181]. A greenhouse experiment conducted by Erskine-Ogden et al. (2016) [182] found that a further increase in aridity and/or N deposition would increase the growth of invasive Mediterranean woody species relative to native competitor species, suggesting that projected increases in aridity would favor the spread of some current invasive forest species in the Mediterranean Basin.

The intentional introduction of Acacia and Eucalyptus species in Portugal, Turkey, and Spain is perhaps the best example of the large impact of invasive forest species in forested areas of the basin [183]. These species have spread to sites other than those where they were planted for afforestation and silvicultural management [183]. For example, Acacia species native to Australia were introduced to stabilize sand dunes but have become dominant, displacing native species [183]. Species of both of these genera have recently taken advantage of forest openness after fires to spread into several forested areas of Portugal [184,185]. Acacia longifolia Andrews is an aggressive species, invading forests and open forests (dehesas) at several sites in Portugal, with notable success at more xeric sites [186]. These invasions could be due to the higher capacity of these species to tolerate high temperatures under water stress compared to their most common native tree competitors [187].

Robinia pseudoacacia L., and Ailanthus altissima Mill. are two of the most invasive and well-established non-native tree species. They have mainly spread from introduced plantations, affecting abandoned land, riverine forests, and road margins, but their capacity to invade established woodlands is lower [188-190]. A. altissima, however, has spread to forested areas [191]. R. pseudoacacia can fix $\mathrm{N}_{2}$ and thus gain advantage in $\mathrm{N}$-limited soils [192]. Invasion by A. altissima and R. pseudoacacia into riverine forests have increased litter production and nutrient cycling, favoring their own spread [190,193]. 


\subsection{Forest Wildfires}

Fire is caused by the integration of climate, topography, changes in land cover (fuel characteristics) and use, and socioeconomic factors. Fire is a frequent and historical longterm endemic disturbance in Mediterranean climates [57]. Large seed banks and the presence of savannoid woodlands are associated with the high resilience of some forest communities that conserve and retain nutrients and where soils quickly recover after a fire [194,195]. The changes in climate and soil in several Mediterranean areas have already increased the risk of fire in the Mediterranean Basin $[41,196]$. The increasing movement of human populations from rural to urban areas frequently tends to favor the build-up of fuel and thus larger and more intense fires. Decreases in the presence and density of human populations, however, reduce the probability of fires caused by humans $[197,198]$. The decrease in forest biomass due to harvesting by humans for energy likely decreases the risk of fire in rural areas undergoing depopulation, since this practice reduces the fire hazard [199]. Depopulation provides a scenario of fewer but larger and more intense fires. We are thus assisting to the intensification of the classical role of fires in Mediterranean landscapes, with extensive and sudden destruction of forests and other ecosystems such as shrubland, grassland, and cropland, greatly impeding natural regeneration [200,201].

Drought has a negative synergy with the increase in more extreme wildfires and mainly extreme summer droughts [5,202-209]. This synergy, when fires follow droughts, promotes shifts in dominance from seeder to resprouter species [205]. Droughts after fires, however, strongly affect post-fire effects on the status of soil nutrients [208]. One hundred years of observational data from 77 sites with and without fires in Spain and France indicated that water stress converted forests in open shrubland by hampering recovery after a fire [209]. Thus, the high fire frequency in some Mediterranean areas can transform forest to shrubland $[210,211]$, and the combined effects of aridity and fire constitute another important positive synergy favoring the conversion of forest to shrubland [209]. The area damaged by fires has increased in the last few decades in several parts of the Mediterranean Basin [212]. Trade-offs between resistance to drought versus resistance to fire have recently been observed, e.g., resistance to embolism (a good adaptation to drought damage) has been negatively correlated with fire tolerance in conifers, which increases flammability when the water content of soil is low [213]. Forest fires in areas with Mediterranean climates greatly degrade the soil, mainly due to an increased erosion on steep slopes from torrential rain $[214,215]$. Fire is a driver of desertification that is linked to a continual positive feedback of higher frequency and intensity of torrential rainfall (associated to climatic change) with an increase of soil erosion, which in turn leads to a loss of soil fertility and thus plant cover. These can also be aggravated by human activities such as excessive livestock pressure, and by increasing the frequency and extend of fires [18]. Fires briefly increase the concentrations of carbon (C) and $\mathrm{N}$ in the upper soil layers [216], but soils frequently lose $\mathrm{C}$ and $\mathrm{N}$ long after a fire $[217,218]$. Modeling has strongly linked past fires with immediately previous droughts [219] and has projected high and important risks of fire in the near future in areas of the Mediterranean Basin where aridity is projected to increase $[220,221]$. The soil temperatures reached during a fire in Mediterranean forested areas is another factor determining the effects of fire on the regeneration of soil quality. Temperatures $<220^{\circ} \mathrm{C}$ have little impact on soil conditions, enabling rapid recovery of vegetation, whereas the effects of temperatures $>220{ }^{\circ} \mathrm{C}$ on soil degradation are more intense, causing a slower recovery of vegetation [222].

\subsection{Soil Fragility and Forest Maintenance and Regeneration}

As discussed previously, low and irregular precipitation is the main factor limiting tree establishment and growth under Mediterranean conditions, which is particularly harmful in areas where the soil has a poor capacity to retain water [223]. The synergistic effect of the unstable balance between the trees and soil water content, together with anthropogenic actions on forest environments and their degradation, which affect floristic composition, act against soil stability and fertility [224-227]. This difficulty in regenerating 
and re-establishing forests after clear-cutting or fire accelerates the conversion of forests to pastures, degraded areas, and ultimately to desertification [228], thus complicating forest sustainability [226]. We must also consider that excessive livestock pressure is still occurring in several forested or potentially forested Mediterranean areas, mainly in the south part, also favoring soil degradation that generally contributes to forest degradation and/or slow regeneration $[229,230]$. Soils, though, can quickly regenerate naturally after a single fire [231], and natural regeneration can be improved by the application of organic amendments to the soil surface after a fire [232], which however cannot be applied on steep slopes where erosion following fires increases after heavy rains, mainly when the fires have also affected the litter cover [233].

The quality of soil is a key aspect ensuring the health and regenerative capacity of Mediterranean forests [228]. Forests are the best types of ground cover for maintaining soil quality and avoiding leaching and degradation in Mediterranean climates [229,234,235]. Conserving and managing forest cover to avoid deforestation as much as possible is thus the best strategy to avoid desertification [224,234]. Various Mediterranean species and even genotypes within species can also control soil processes mediated by microbes [236].

\subsection{High Diversity at Risk}

The Mediterranean Basin is a focus of biological diversity [237-239]. Forests covered an estimated $82 \%$ of the landscape before the first human impacts thousands of years ago [239]. Forest trees and shrubs contribute directly and indirectly to the plant diversity, directly since the basin has a high diversity of tree species $[237,240]$. For example, the European Mediterranean region includes an unexpectedly high number of tree taxa, almost 200 more taxa than in central Europe [239]. Trees have indirectly contributed to diversity since Mediterranean forests are foci of diversity of taxa other than plants [241]. Mediterranean forests, however, are not only key ecosystems for maintaining Mediterranean plant diversity but are also foci of high diversities of microbes [242-244], fungi [245,246], lichens [247], and animals [247-249], all of which are very sensitive to the impacts of drought, fire, and other disturbances $[250,251]$. Tree forest diversity controls soil invertebrate diversity, because of more mixed-litter coming from distinct tree species is associated to more diverse soil invertebrate communities [252].

Late-successional forests dominated by Quercus species sustain a higher diversity of higher plants than do secondary forests dominated by Pinus species [253], but Pinus forests can be associated with higher fungal diversity than Quercus forests [245]. Kouba et al. (2015) [254] reported that communities dominated by early-, intermediate-, and latesuccessional species have similar levels of plant diversity at different stages of regeneration due to historical land uses and perturbations. This study also reported that historical land management has driven the current lack of late successional species in forested areas of the Mediterranean Basin. Alvarez et al. (2009) [255] reported similar results. Another study found that the replacement of $Q$. suber with $P$. pinaster was associated with a loss of plant diversity [253]. The richness of bird species (both generalists and specialists) tends to increase in more advanced successional forest stages when the diversity of tree species increases, but richness tends to decrease when the forest cover is very closed and dense [256]. Birds consistently maintain richer communities with higher diversity in areas with forest patches of different sizes and species compositions that provide many habitats [257]. A management strategy avoiding landscape homogenization and excessive fuel accumulation and thus fire risk is the best scenario for reducing fire frequency and thus preserving taxonomic diversity [258-260]. Biodiversity in Mediterranean areas has been widely monitored and quantified, so identifying species indicative of different levels of diversity is feasible in Mediterranean landscapes [261]. Moreover, current warming has had positive effects on angiosperm Mediterranean forests and a negative effect on gymnosperms Mediterranean forest as observed in Spain due to hydraulic traits and reproductive success [262,263]. 


\subsection{Depopulation and Abandonment of Rural Areas}

The abandonment of rural areas in several parts of the Mediterranean Basin in the last 80-100 years has been associated with an increase in forest cover [264]. For example, forest cover was continuously reduced in Catalonia from 1868 to the 1950s, but forest cover has since continuously expanded with the abandonment of traditional forest activities and mainly with the abandonment of cropland [265]. These secondary new forests in the initial-medium stages of the succession process, however, have frequently poor age structure, and frequently non adequate density, diversity, and maturity and are thus more prone to wildfires [265]. The global strategy to overcome this situation has been a combination of re-farming establishment and extensive livestock and sustainable forest management $[265,266]$.

\section{Human Management. How Can it Help Mediterranean Forest Health and Conservation?}

We have accumulated a large amount of data in recent years from a variety of studies providing an overview of how and what type of land management could realistically and sustainably help conserve the diversity of Mediterranean forested areas (Figure 1). More information on how to manage the forest structure could help us improve the capacity of Mediterranean forests to cope with drought conditions and how and where the control of forest density could help us reach the desired management objectives [267]. Different management and economic activities can have very different levels of impact. For example, sustainable cork production in $Q$. suber forests is completely compatible with forest cover, health, and regeneration, whereas cattle grazing and establishing herbaceous crops among trees degrades the soil and impedes the maintenance of forest cover in $Q$. suber communities [268].

The maintenance of forest patches between croplands in rural areas can be a suitable management strategy throughout territories with adequate planning [269-271]. Positive relationships between forest-patch area and species richness can be optimal for patches of about 10 ha, when diversity remains stable [269]. The appropriate management of livestock and logging ensures the equal representation of different stages of forest succession among forest patches of different sizes, which would be the best tool to maintain the diversity of woody plants and forest services among landscapes, as some studies strongly suggest [270,272]. Gonzalez-Moreno et al. (2011) [270] reported that patches of secondary forest dominated by pines contained more plant species than patches of mature forest dominated by evergreen oak species. Moreover, the more diverse the tree species of a Mediterranean forest, the more diverse the soil trophic webs, as a result of a larger litter composition variability [241].

The extensive management of livestock as a potential alternative tool for maintaining biodiversity and avoiding the risk of fire in Mediterranean landscapes has recently been debated [273]. The results are not completely satisfactory and do not currently allow a general conclusion. Cattle grazing in a Mediterranean forest preferred woody plants, potentially reducing the number of flammable taxa, but having generally detrimental effects on plant-community health, and the cattle had to be supplied with supplementary food in the long term [273]. Decreasing forest and woodland density to increase the vitality and survival of individual trees under drought conditions must be preceded by accurately evaluating the present situation and a realistic final objective in the line to preserve a community with the maximum of diversity and biomass and also resistance to environmental stress. Late successional Mediterranean forest species such as $Q$. suber mainly need the presence of old large individuals to successfully recruit seedlings [247]. The increased extension of open bare soil does not allow the establishment and/or permanence of these late-successional Mediterranean tree species.

Reforestation and afforestation are the most direct human actions that can counteract the progressive degradation of forests in Mediterranean landscapes. These actions can currently recuperate savannoid and/or forest structures in several Mediterranean areas 
from the practical loss of natural forest regeneration by the increasing extensive replacement of forests by shrub communities and even by desertification $[18,274,275]$. Reforestation and afforestation, mainly in semi-arid and/or burned areas, can conserve soil, C, and nutrients in the system but must be appropriately managed to avoid as many impacts as possible $[276,277]$.

Reforestation and afforestation with more than one species, accounting for microspatial variability, have been successful for creating diverse landscapes $[259,278,279]$. The combination of Pinus and Quercus species or Quercus species alone have successfully ensured maximal biodiversity $[279,280]$ and soil conservation $[280,281]$ at mesic sites. P. halepensis strongly competes for water, mainly in the upper soil layers, impeding the establishment of shrubs with shallow root systems [282-284]. Reforestation and afforestation with oaks alone or with Pinus are thus advisable to ensure maximal diversity of understory plants allowed by the climatic conditions.

The use of nursery species that provide shade can allow the replantation of semideciduous oaks when the repopulation combines them with evergreen oaks such as Q. ilex [285] or planting shrubs in reforestations with mesic pines such as P. nigra [286]. $P$. halepensis, however, has been the best species in most studies, reforestations and afforestation in semi-arid areas with a mean annual precipitation of 300-400 $\mathrm{mm}$ [287-290]. The success of reforestation and afforestation in semi-arid areas can be improved by fertilization [291]. The diversity of understory plants in P. halepensis forests can be improved by planting appropriate shrubs in stands with specific pine densities [277]. Some animal communities have also been improved in stands afforested with $P$. halepensis in semi-arid Mediterranean areas [292]. Another problem, mainly in countries in phases of economic development and expansion, is the necessity to manage forests to reduce $\mathrm{CO}_{2}$ emissions in the framework of the Kyoto protocol [293], which increases the need for appropriate forest management, reforestation, and afforestation in the Mediterranean Basin.

The use of mulches and organic amendments [294-296] and even of soil conditioners with water-absorbing polymers [297,298] substantially favors the early establishment of tree seedlings. The use of composite amendments (sewage sludge plus green waste) can also be useful if the amounts of $\mathrm{P}$ and trace elements are controlled to avoid environmental pollution [200]. Organic amendments can generally efficiently counteract the most common first step of soil degradation by water erosion and wildfires: The loss of organic matter [299-301]. We recommend choosing the best species identified by previous studies to ensure the success of reforestation and afforestation [279,302,303].

Management practices after reforestation or afforestation are also important for increasing the probability of success [304]. Periodic reduction of vegetation, such as shrubs and grasses, can improve the survival and growth of planted trees [304]. Appropriate forest management, with a good combination of forest patches of different sizes and successional stages together with other ecosystems, such as cropland, is also an adequate tool to improve the capacity to store $C$ [305]. Appropriate management is also necessary to maintain natural Mediterranean forests in their current structure and areas [306]. An adequate level of thinning a few years after a fire can enhance forest regeneration and allow the control of fuel load for possible future forest fires, both by seeder species such as $P$. halepensis and by resprouter species such as Q. ilex [307].

Forest conservation can thus be improved by the good management of burned areas or areas with degraded soil. We should first reduce or avoid some practices. Salvage logging is common in several post-fire areas but has been very detrimental to forest regeneration due to soil degradation [308]. Conserving a specific amount and density of logging remnants after a fire has been associated with the better conservation of bird abundance and richness [309]. Various practices of forest management can have positive or negative effects on the post-fire regeneration of Q. suber trees, e.g., traditional coppicing is considered necessary, but branch pruning should be avoided [310]. The use of fire retardants in the dry season to prevent and/or easily control forest fires can increase 
the alteration of leachates (high cation concentrations and $\mathrm{pH}$ ) during periods of rain, suggesting a risk to the quality of freshwater bodies [311].

Studies thus suggest that an integrative approach would be the most efficient global management strategy to prevent fire, ensure adequate forest cover, maintain forest quality, and favor regeneration in current Mediterranean forested areas. This strategy should be based on optimal and moderate forest thinning and livestock pressure and on the appropriate management of the distribution of forest species based on the best native species at each site. This strategy should be complemented in non-urban areas with the maintenance of cropland and adequate and sustainable socioeconomic conditions for rural populations, avoiding depopulation and land abandonment and should be the key global strategy to conserve soil quality and biodiversity, preserve forests, and prevent fire [312]. We must, however, also account for the different realities of southern Europe and northern Africa, that are driven towards an extreme opposed situation. Management in southern Europe should be addressed based on the need to avoid excessive rural abandonment and to maintain a diverse landscape [313], but the scenario in northern Africa is currently different. The exponential increase in population in the Maghreb region led to the expansion of cropland in marginal areas initially dominated by woodland, leading to the ploughing of slopes for livestock in the remaining natural non-cropland areas, with the consequent degradation of soil [298].

Land abandonment followed by forest re-establishment, however, should not be a problem, despite the increased risk of fire. First, the conversion of abandoned cropland to forest has been associated with improved soil stability [314,315]. Second, the increase in forest fires can be counteracted by the appropriate management of new forested areas if the global economic exploitation of rural areas, including forest management (with all the above measures), allow the maintenance of sustainable human activities in rural Mediterranean areas.

In summary, aridity is the main climatic constraint for Mediterranean forests, that should be taken into account in forest management. These drought-driven alterations can become stronger if climate change, its associated disturbances (e.g., by floods, droughts, heat waves, and forest fires), and changes in other components of global change (especially the changes of land use, pollution, and overexploitation of resources) continue at current rates or are enhanced. Therefore, we need to know more about properly managing forests to increase their resistance to drought and the interacting disturbances. Information is currently available for appropriate species composition, plant density, and the use of shrubs, but less is known about other important factors such as improving soil conditions to ensure a good supply of nutrients.

Land-use planning is a key "pending question" in several areas of the Mediterranean Basin. A strong alliance to fight against the loss of forest quantity and quality is among the main challenges to be addressed both to avoid excessive depopulation of rural forested areas an unmanaged secondary forest expansion in Mediterranean Europe, and on the other extreme, to the progressive population expansion implying over-exploitation and forest degradation and loss in North Africa. All the data strongly suggest that maintaining biodiversity, as well as a variety of goods and services from cropland and forested areas will be necessary to reach this objective, combining forest patches of different sizes with other communities, including the most appropriate crops for maintaining environmental quality and food security as much as possible, allowing economic sources for the maintenance of an optimal human density. The management of forested areas, and of natural areas in general, should incorporate a hierarchical landscape planning at different scales, including a large-scale plan that considers the combination of areas of different types, multiple users, and the effects of disturbances, such as forest fires, floodings, and especially drought, to a minor-scale action such as the improvement of stakeholders education and tools availability for an adequate management of their territories.

Funding: The authors would like to acknowledge the financial support from the Spanish government grant PID2019-110521GB-I00, the Fundación Areces grant ELEMENTAL-CLIMATE-2021, the Catalan 
Government grant SGR-2017-1005, the European Research Council Synergy grant ERC-SyG-2013610028 IMBALANCE-P, and EFIMED Mediterranean Forest Research Agenda.

Institutional Review Board Statement: Not applicable.

Informed Consent Statement: Not applicable.

Data Availability Statement: The datasets in this study are available within this article.

Conflicts of Interest: The authors declare no conflict of interest.

\section{References}

1. Di Castri, F.; Mooney, H.A. Mediterranean Type Ecosystems: Origin and Structure; Springer: New York, NY, USA, 1973 ; pp. 11-19.

2. Di Castri, F. Mediterranean-type shrublands of the world. In Mediterranean-Type Shrublands; Di Castri, F., Goodall, D.W., Specht, R.L., Eds.; Elsevier: Amsterdam, The Netherlands, 1981; pp. 1-52.

3. Brauch, H.G. Towards a fourth phase of research on human and environmental security and peace: Conceptualconclusions. In Security and the Environment in the Mediterranean: Conceptualising Security and Environmental Conflicts; Braunch, H.G., Liotta, P.H., Marquina, A., Rogers, P.F., Selim, M.E.S., Eds.; Springer: Berlin, Germany, 2003; pp. 919-953.

4. Doblas-Miranda, E.; Martínez-Vilalta, J.; Lloret, F.; Álvarez, A.; Ávila, A.; Bonet, F.J.; Brotons, L.; Castro, J.; Curiel Yuste, J.; Díaz, M.; et al. Reassessing global change research priorities in Mediterranean terrestrial ecosystems: How far have we come and where do we go from here? Glob. Ecol. Biogeogr. 2015, 24, 25-43. [CrossRef]

5. Barredo, J.I.; Caudullo, G.; Dosio, A. Mediterranean habitat loss under future climate conditions: Assessing impacts on Nature 2000 protected area network. Appl. Geogr. 2016, 75, 83-92. [CrossRef]

6. Anav, A.; Mariotti, A. Sensitivity of natural vegetation to climate change in the Euro-Mediterranean area. Clim. Res. 2011, 46, 27-292. [CrossRef]

7. Alessandri, A.; De Felice, M.; Zeng, N.; Mariotti, A.; Pan, Y.; Cherchi, A.; Lee, J.Y.; Wang, B.; Ha, K.J.; Ritu, P.; et al. Robust assessment of the expansion and retreat of Mediterranean climate in the 21st century. Sci. Rep. 2014, 4, 7211. [CrossRef]

8. Valladares, F.; Benavides, R.; Rabasa, S.G.; Díaz, M.; Pausas, J.G.; Paula, S.; Simonson, W.D. Global change and Mediterranean forests: Current impacts and potential responses. In Forests and Global Change; Ecological Reviews; Coomes, D.A., Burslem, D.F.R.P., Simonson, W.D., Eds.; Cambridge University Press: Cambridge, UK, 2014; pp. 47-75.

9. Peñuelas, J.; Gracia, C.; Alistair Jump, I.F.; Carnicer, J.; Coll, M.; Lloret, F.; Yuste, J.C.; Estiarte, M.; Rutishauser, T.; Ogaya, R. Introducing the climate change effects on Mediterranean forest ecosystems: Observation, experimentation, simulation, and management. Forêt Médit. 2010, 31, 357-362.

10. FAO. State of the Mediterranean Forest Publishes by the Food and Agriculture Organization of the United Nations and Plan Bleu, Regional Activity Center of UN Environmental/Mediterranean Action Plan Rome; FAO: Rome, Italy, 2018.

11. Un News. "At Risk" Mediterranean Forest Make "Vital Contributions" to Development. 2018. Available online: https: //news.un.org/en/story/2018/11/1026761 (accessed on 23 February 2020).

12. Giorgi, F. Climate change hot-spots. Geophys. Res. Let. 2006, 33, L08707. [CrossRef]

13. Piñol, J.; Terradas, J.; Lloret, F. Climate warming, wildfire hazard, and wildfire occurrence in coastal eastern Spain. Int. J. Wildlfire 1998, 11, 95-106.

14. Esteban-Parra, M.J.; Rodrigo, F.S.; Castro-Diez, Y. Spatial and temporal patterns of precipitation in Spain for the period 1880-1992. Int. J. Climatol. 1998, 18, 1557-1574. [CrossRef]

15. Peñuelas, J.; Filella, I.; Sabate, S.; Gracia, C. Natural Systems: Terrestrial Ecosystems; Llebot, J.E., Ed.; Institut d'Estudis Catalans: Barcelona, Spain, 2005; pp. 517-553.

16. Sillmann, J.; Kharin, V.V.; Zwiers, F.W.; Zhang, X.; Bronaugh, D. Climate extremes indices in the CMIP5 multimodel ensemble: Part 2. Future climate projections. J. Geophys. Res. Atmos. 2013, 118, 2473-2493. [CrossRef]

17. Gaol, X.; Giorgi, F. Increased aridity in the Mediterranean region under greenhouse gas forcing estimated from high resolution simulations with a regional climate model. Glob. Planet. Chang. 2008, 62, 195-209.

18. Sardans, J.; Peñuelas, J. Plant-soil interactions in Mediterranean forest and shrublands: Impacts of climatic change. Plant Soil 2013, 365, 1-33. [CrossRef] [PubMed]

19. Solomou, A.D.; Proutsos, N.D.; Karetsos, G.; Tsagari, K. Effects of climate change on vegetation in Mediterranean forests: A review. Intern. J. Environ. Agric. Biotechn. 2017, 2, 240-247. [CrossRef]

20. Specht, R.L. Dark island heath (Ninety-mile Plain. South Australia). VII The effect of fertilisers on composition and growth. Aus. J. Bot. 1963, 23, 1950-1960.

21. Hanley, M.; Fenner, M. Growth of Aleppo pine (Pinus halepensis) deprived of single mineral nutrients. J. Med. Ecol. 2001, 2, 107-112.

22. Terradas, J. Ecología de la Vegetación. De la Ecofisiología de las Plantas a la Dinámica de Comunidades y Paisajes; Omega: Barcelona, Spain, 2001.

23. Sardans, J.; Rodà, F.; Peñuelas, J. Phosphorus limitation and competitive capacities of Pinus halepensis and Quercus ilex subsp. rotundifolia on different soils. Plant Ecol. 2004, 174, 305-317. [CrossRef] 
24. Niinemets, U.; Tenhunen, J.D.; Canta, N.R.; Chaves, M.M.; Faria, T.; Pereira, J.S.; Reynolds, J.F. Interactive effects of nitrogen and phosphorus on the acclimation potential of foliage photosynthetic properties of cork oak, Quercus suber, to elevated atmospheric $\mathrm{CO}_{2}$ concentrations. Glob. Chang. Biol. 1999, 5, 455-470. [CrossRef]

25. Fernández Nogueira, D.; Corbelle Rico, E. Cambios en los usos de suelo en la Península Ibérica: Un meta-análisis para el período 1985-2015. Biblio. Revista Bibliogr.Geogr.Cien. Soc. 2017, 22, 215.

26. Padilla, F.M.; Pugnaire, F.I. Rooting depth and soil moisture control Mediterranean woody seedling survival during drought. Func. Ecol. 2007, 21, 489-495. [CrossRef]

27. Misson, L.; Degueldre, D.; Collin, C.; Rodríguez, R.; Rocheteau, A.; Ourcival, J.M.; Rambal, S. Phenological response to extreme droughts in a Mediterranean forest. Glob. Change. Biol. 2011, 17, 1036-1048. [CrossRef]

28. Martin-StPaul, N.K.; Limousin, J.M.; Vogt-Schilb, H.; Rodriguez-Calcerrada, J.; Rambal, S.; Longepierre, D.; Misson, L. The temporal response to drought in a Mediterranean evergreen tree: Comparing a regional precipitation gradient and a throughfall exclusion experiment. Glob. Chang. Biol. 2013, 19, 2413-2426. [CrossRef]

29. Bongers, F.J.; Olmo, M.; Lopez-Iglesias, B.; Anten, N.P.R.; Villar, R. Drought responses, phenotypic plasticity and survival of Mediterranean species in two different microclimatic sites. Plant Biol. 2017, 19, 386-395. [CrossRef] [PubMed]

30. Castagneri, D.; Regev, L.; Boaretto, E.; Carrer, M. Xylem anatomical traits reveal different strategies of two Mediterranean oaks to cope with drought and warming. Environ. Exp. Bot. 2017, 133, 128-138. [CrossRef]

31. Limousin, J.M.; Rambal, S.; Ourcival, J.M.; Rodriguez-Calcerrada, J.; Perez-Ramos, I.M.; Rodriguez-Cortina, R.; Misson, L.; Joffre, R. Morphological and phenological shoot plasticity in a Mediterranean evergreen oak facing long-term increased drought. Oecologia 2012, 169, 565-577. [CrossRef]

32. Forner, A.; Aranda, I.; Granier, A.; Valladares, F. Differential impact of the most extreme drought event over the last half century on growth and sap flow in two coexisting Mediterranean trees. Plant Ecol. 2014, 215, 703-719. [CrossRef]

33. Piayda, A.; Dubbert, M.; Rebmann, C.; Kolle, O.; Silva, F.C.E.; Correia, A.; Pereira, J.S.; Werner, C.; Cuntz, M. Drought impact on carbon and water cycling in a Mediterranean Quercus suber L. woodland during the extreme drought event in 2012. Biogeosciences 2014, 11, 7159-7178. [CrossRef]

34. Vicente-Serrano, S.M.; Lopez-Moreno, J.I.; Begueira, S.; Lorenzo-Lacruz, J.; Sanchez-Lorenzo, A.; Garcia-Ruiz, J.M.; Azorin-Molina, C.; Morán-Tejeda, E.; Revuelto, J.; Trigo, R.; et al. Evidence of increasing drought severity caused by temperatura rise in southern Europe. Envron. Res. Lett. 2014, 9, 044001. [CrossRef]

35. Siscard, P.; Dalstein-Richier, L. Health and vitally assessment of two common pine species in the context of climate change in southern Europe. Environ. Pollut. 2015, 137, 235-245.

36. Medrano, H.; Flexas, J.; Galmés, J. Variability in water use efficiency at the leaf level among Mediterranean plants with different growth forms. Plant Soil 2009, 317, 17-29. [CrossRef]

37. Vicente-Serrano, S.M.; Lasanta, T.; Gracia, C. Aridification determines changes in forest growth in Pinus halepensis forest under semiarid Mediterranean climate conditions. Agric. For. Meteorol. 2010, 150, 614-628. [CrossRef]

38. IPCC Working Group, I. Climate Change 2007: The physical Science Basis. Contribution of working group I. In Fourth Assessment Report on the Intergovermental Panel on Climate Chnge; Solomon, S., Qin, D., Manning, M., Chen, Z., Marquis, M., Averyt, K.B., Tignor, M., Miller, H.L., Eds.; Cambridge University Press: Cambridge, UK, 2007.

39. Sarris, D.; Christodoulakis, D.; Körner, C. Impact of recent climatic change on growth of low elevation eastern Mediterranean forest trees. Clim. Chang. 2011, 106, 203-223. [CrossRef]

40. Taibi, S.; Meddi, M.; Mahe, G. Seasonal rainfall variability in the southern Mediterranean border: Observation, regional model simulations and future climate projections. Atmosfera 2019, 32, 39-54. [CrossRef]

41. Ozturk, M.; Gucel, S.; Kucuk, M.; Sakcali, S. Forest diversity, climate change and forest fires in the Mediterranean region of Turkey. J. Environ. Biol. 2010, 31, 1-9.

42. Tramblay, Y.; Somot, S. Future evolution of extreme precipitation in the Mediterranean. Clim Chang. 2018, 151, 289-302. [CrossRef]

43. Stocker, T.F.; Qin, D.; Plattner, G.-K.; Tignor, M.; Allen, S.K.; Boschung, J.; Nauels, A.; Xia, Y.; Bex, V.; Midgley, P.M. (Eds.) IPCC Climate Change 2013: The Physical Science Basis. Contribution of Working Group I to the Fifth Assessment Report of the Intergovernmental Panel on Climate Change; Cambridge University Press: Cambridge, UK; New York, NY, USA, 2013; 1535p.

44. Pena-Gallardo, M.; Vicente-Serrano, S.M.; Camarero, J.J.; Gazol, A.; Sanchez-Salguero, R.; Dominguez-Castro, F.; El Kenawy, A.; Beguería-Portugés, S.; Gutiérrez, E.; De Luis, M.; et al. Drought snesitiveness on forest growth in Peninsular Spain and the Balearic Islands. Forests 2018, 9, 524. [CrossRef]

45. Tognetti, R.; Lasserre, B.; Di Febbraro, M.; Marchetti, M. Modelling regional drought-stress indices for beech forest in Mediterranean mountains based on tree-ring data. Agric. For. Meteorol. 2019, 265, 110-120. [CrossRef]

46. Barbeta, A.; Mejía-Chang, M.; Ogaya, R.; Voltas, J.; Dawson, T.E.; Peñuelas, J. The combined effects of a long-term experimental drought and an extreme drought on the use of plant-water sources in a Mediterranean forest. Glob. Chang. Biol. 2015, 21, 1213-1225. [CrossRef]

47. Ogaya, R.; Penuelas, J. Tree growth, mortality, and above-ground biomass accumulation in a holm oak forest under a five-year experimental field drought. Plant Ecol. 2007, 189, 291-299. [CrossRef]

48. Barbeta, A.; Ogaya, R.; Peñuelas, J. Dampening effects of long-term experimental drought on growth and mortality rates of a holm oak forest. Glob. Chang. Biol. 2013, 19, 3133-3144. [CrossRef] [PubMed]

49. Peñuelas, J.; Lloret, F.; Montoya, R. Severe drought effects on Mediterranean woody flora in Spain. For. Sci. 2001, 47, $214-218$. 
50. Romero, R.; Guijarro, J.A.; Ramis, C.; Alonso, S. A 30-year (1964-1993) daily data base for the Spanish Mediterranean regions: First exploratory study. Int. J. Climatol. 1998, 18, 541-560. [CrossRef]

51. Frei, C.; Schär, C.; Lüthi, D.; Davies, H.C. Heavy precipitation processes in a warmer climate. Geophys. Res. Lett. 1998, 25, 1431-1434. [CrossRef]

52. Garcia, C.; Hernandez, T.; Roldan, A.; Martin, A. Effect of plant cover decline on chemical and microbiological parameters under Mediterranean climate. Soil Biol. Biochem. 2002, 34, 635-642. [CrossRef]

53. García-Fayos, P.; Bochet, E. Indication of antagonistic interaction between climate change and erosion on plant species richness and soil properties in semiarid Mediterranean ecosystems. Glob. Chang. Biol. 2009, 15, 306-308. [CrossRef]

54. Moreno-de las Heras, M.M.; Bochet, E.; Monleon, V.; Espigares, T.; Nicolau, J.M.; Molina, M.J.; Garcia-Fayos, P. Aridity indices nonlinear effects of human disturbance on precipitation-use efficiency of Iberian woodlands. Ecosystems 2018, 21, 1295-1305. [CrossRef]

55. Ruiz-Sinoga, J.D.; Gabarón Galeote, M.A.; Martínez Murillo, J.F.; Garcia Marín, R. Vegetation strategies for soil consumption along a pluviometric gradient in southern Spain. Catena 2011, 84, 12-20. [CrossRef]

56. Conacher, A.J. Summary and conclusions. In Land Degradation in Mediterranean Environments of the World: Nature and Extent, Causes and Solutions; Conacher, A.J., Sala, M., Eds.; John Wiley \& Sons: Chichester, UK, 1998; pp. 449-457.

57. Keeley, J.E.; Bond, W.J.; Bradstock, R.A.; Pausas, J.G.; Rundel, P.W. Fire in Mediterranean Ecosystems: Ecology, Evolution and Management; Cambridge University Press: Cambridge, UK, 2012.

58. Peñuelas, J.; Sardans, J.; Filella, I.; Estiarte, M.; Llusià, J.; Ogaya, R.; Carnicer, J.; Bartrons, M.; Rivas-Ubach, A.; Grau, O.; et al. Assessment of the impacts of climate change on Mediterranean terrestrial ecosystems based on data from field experiments and long-term monitored field gradients in Catalonia. Environ. Exp. Bot. 2018, 152, 49-59. [CrossRef]

59. Peñuelas, J.; Boada, M. A global-induced biome shift in the Montseny mountains (NE Spain). Glob. Chang. Biol. 2003, 9, 131-140. [CrossRef]

60. Batllori, E.; Gutierrez, E. Regional tree line dynamics in response to global change in the Pyrennes. J. Ecol. 2008, 96, 1275-1288. [CrossRef]

61. Stella, J.C.; Riddle, J.; Piegay, H.; Gagnage, M.; Tremelo, M.L. Climate and local geomorphic interactions drive patterns of riparian forest decline along a Mediteerranean Basin river. Geomorphology 2013, 202, 101-114. [CrossRef]

62. Boddziewicz, M.; Fernández-Martínez, M.; Bonal, R.; Belmonte, J.; Espelta, J.M. The Moran effect and Environmental vetoes: Phenological synchrony and drought drive seed production in a Mediterranean oak. Proc. R. Soc. B 2017, $284,1784$.

63. Sanchez-Salguero, R.; Camarero, J.J.; Grau, J.M.; de la Cruz, A.C.; Minaya, M.; Fernanderz-Cancio, A. Analysing atmospheric processes and climatic drivers of tree defoliation to determine forest vulnerability to climate warming. Forests $2017,8,13$. [CrossRef]

64. Brasier, C.M. Phytophthora cinnamoni and oak decline in southern Europe. Environmental constrains including climate change. An. Sci. For. 1996, 53, 347-358. [CrossRef]

65. Corcobado, T.; Cubera, E.; Juarez, E.; Moreno, G.; Solla, A. Drought events determine performance of Quercus ilex seedlings and increase their susceptibility to Phytophthora cinnamomi. Agric. For. Meteorol. 2014, 192, 1-8. [CrossRef]

66. Natalini, F.; Alejano, R.; Vazquez-Pique, J.; Canellas, I.; Gea-Izquierdo, G. The role of climate change in the widespread mortality of holm oak in open woodlands of Southwestern Spain. Dendrochronologia 2016, 38, 51-60. [CrossRef]

67. Gentilesca, T.; Camarero, J.J.; Colangelo, M.; Nole, A.; Ripullone, F. Drought-induced oak decline in the western Mediterranean región: An overview on current evidences, mechanisms and Management options to improve forest resilence. IFor. Biogeosci. For. 2017, 10, 796-806. [CrossRef]

68. Camarero, J.J.; Alvarez-Taboada, F.; Hevia, A.; Castedo-Dorado, F. Radial growth and Wood density reflect the impacts and susceptibility to defoliation by gypsy moth and climate in Radiata pine. Front. Plant Sci. 2018, 9, 1582. [CrossRef]

69. Avila, J.M.; Gallardo, A.; Gomez-Aparicio, L. Pathogen-induced tree mortality interacts with predicted climate change to alter soil respiration and nutrient availability in Mediterranean systems. Biogeochemistry 2019, 142, 53-71. [CrossRef]

70. Gea-Izquierdo, G.; Feriz, M.; Garcia-Garrido, S.; Aguin, O.; Elvira-Recuenco, M.; Hernandez-Escribano, L.; Martin-Benito, D.; Raposo, R. Synergistic abiotic and biotic stressors explain widespread decline of Pinus pinaster in a mixed forest. Sci. Total Environ. 2019, 685, 963-975. [CrossRef]

71. Dominguez-Begines, J.; De Deyn, G.B.; Garcia, L.V.; Eisenhauer, N.; Gomez-Aparicio, L. Cascading spatial and trophic impacts of oak decline on the soil Food web. J. Ecol. 2019, 107, 1199-1214. [CrossRef]

72. Rodriguez, A.; Duran, J.; Rey, A.; Boudouris, I.; Valladares, F.; Gallardo, A.; Yuste, J.C. Interaction effects of forest die-off and drying-rewetting cycles on C and N mineralization. Geoderma 2019, 333, 81-89. [CrossRef]

73. Galiano, L.; Martínez-Vilalta, J.; Sabate, S.; Lloret, F. Determinants of drought effects on Crown condition and their relationship with depletion of carbon reserves in a Mediterranean holm oak forest. Tree Physiol. 2012, 32, 478-489. [CrossRef] [PubMed]

74. Lapa, G.; Morandini, F.; Ferrat, L. Sap flow and photosynthetic response to climate and drought of Pinus nigra in a Mediterranean natural forest. Trees Struc. Funct. 2017, 31, 1711-1721. [CrossRef]

75. Rambal, S.; Ourcival, J.M.; Joffre, R.; Mouillot, F.; Nouvellon, Y.; Reichstein, M.; Rocheteau, A. Drought controls over conductance and assimilation of a Mediterranean evergreen ecosystem: Scaling from leaf to canopy. Glob. Chang. Biol. 2003, 9, $1813-1824$. [CrossRef] 
76. Lempereur, M.; Limousin, J.M.; Guibal, F.; Ourcival, J.M.; Rambal, S.; Ruffault, J.; Mouillot, F. Recent climate hiatus revealed dual control by temperature and drought on the stem growth of Mediterranean Quercus ilex. Glob. Chang. Biol. 2017, $23,42-55$. [CrossRef] [PubMed]

77. Sanchez-Salguero, R.; Navarro-Cerrillo, R.M.; Camarero, J.J.; Fernandez-Concio, A. Drought-induced growth decline of Aleppo and maritime pine forests in south-eastern Spain. For. Syst. 2010, 19, 458-469. [CrossRef]

78. Manrique-Alba, A.; Ruiz-Yanetti, S.; Moutahir, H.; Novak, K.; De Luis, M.; Bellot, J. Soil moisture and its role in growth-climate relationships across an aridity gradient in semiarid Pinus halepensis forest. Sci. Total Environ. 2017, 574, 982-990. [CrossRef]

79. Buras, A.; Menzel, A. Projecting tree species composition changes of European forest for 2061-2090 under RCP 4.5 and RCP 8.5 scenarios. Front. Plant Sci. 2019, 9, 1986. [CrossRef] [PubMed]

80. Rivas-Ubach, A.; Barbeta, A.; Sardans, J.; Guenther, A.; Ogaya, R.; Oravec, M.; Urban, O.; Penuelas, J. Topsoil depth substantially influences the response to drought of the foliar metabolomes of Mediterranean forest. Persp. Plant Ecol. Evol. Syst. 2016, 21, 41-54. [CrossRef]

81. Hickler, T.; Vohland, K.; Feehan, J.; Miller, P.A.; Smith, B.; Costa, L.; Giesecke, T.; Fronzek, S.; Carter, T.R.; Cramer, W.; et al. Projecting the future distribution of European potential natural vegetation zones with a generalized, tree species-based dynamic vegetation model. Glob. Ecol. Biogeogr. 2012, 21, 50-63. [CrossRef]

82. Fernandez-Manjares, J.F.; Ruiz-Benito, P.; Zavala, M.A.; Camarero, J.J.; Pulido, F.; Proença, V.; Navarro, L.; Sansilvestri, R.; Granda, E.; Marqués, L.; et al. Forest adaptation to climate change along steep Ecological gradients: The case of the Mediterraneantemperature transition in South-Western Europe. Sustainability 2018, 10, 3065. [CrossRef]

83. Rodriguez-Vallejo, C.; Navarro-Cerrillo, R.M. Contrasting response to drought and climate of planterd and natural Pinus pinaster Aiton forest in Southern Spain. Forests 2019, 10, 603. [CrossRef]

84. Linares, J.C.; Delgado-Huertas, A.; Camarero, J.J.; Merino, J.; Carreira, J.A. Competition and drought limit the response of water-use efficiency to rising atmospheric carbon dioxide in the Mediterranean fir Abies pinsapo. Oecologia 2009, 161, 611-624. [CrossRef]

85. Batllori, E.; de Caceres, M.; Brotons, L.; Ackerly, D.D.; Moritz, M.A.; Lloret, F. Compound fire-drought regimes promote ecosystem transitions in Mediterranean ecosystems. J. Ecol. 2019, 107, 1187-1198. [CrossRef]

86. Liu, D.; Ogaya, R.; Barbeta, A.; Yang, X.; Peñuelas, J. Contrasting impacts of continuous moderate drought and episodic severe droughts on the aboveground-biomass increment and litterfall of three coexisting Mediterranean Woody species. Glob. Chang. Biol. 2015, 21, 4196-4209. [CrossRef] [PubMed]

87. Liu, D.J.; Ogaya, R.; Barbeta, A.; Yang, X.H.; Peñuelas, J. Long-term experimental drought combined with natural extremes accelerate vegetation shift in a Mediterrranean holm oak forest. Environ. Exp. Bot. 2018, 151, 1-11. [CrossRef]

88. Acacio, V.; Dias, F.S.; Catry, F.X.; Rocha, M.; Moreira, F. Landscape dynamics in Mediterranean oak forest under global change: Understanding the role of anthropogenic and Environmental drivers across forest types. Glob Chang. Biol. 2017, 23, 1199-1217. [CrossRef]

89. Flores-Renteria, D.; Yuste, J.; Rincon, A.; Brearley, F.Q.; Garcia-Gil, J.C.; Valladares, F. Habitat fragmentation can modulate drought effects on the plant-soil-microbial system in Mediterranean holm oak (Quercus ilex) forests. Microb. Ecol. 2015, 69, 798-812. [CrossRef]

90. Touchan, R.; Anchukaitis, K.J.; Meko, D.M.; Attalah, S.; Baisan, C.; Aloui, A. Long term context for recent drought in northwestern Africa. Geophys. Res. Let. 2008, 35, L13705. [CrossRef]

91. Slimani, S.; Derridj, A.; Gutierrez, E. Ecological response of Cedrus atlantica to climate variability in the Massif of Guetiane (Algeria). For. Syst. 2014, 23, 448-460. [CrossRef]

92. Bouachir, B.B.; Khorchani, A.; Guibal, F.; El Aouni, M.H.; Khaldi, A. Dendroecological study of Pinus halepensis and Pinus pinea in northeast coastal dunes in Tunisia according to distance from the shoreline and dieback intensity. Dendrochronologia 2017, 45 , 62-72. [CrossRef]

93. Kabiel, H.F.; Hegazy, A.K.; Lovett-Doust, L.; Al-Rowaily, S.L.; Al Borki, A.E.N.S. Ecological assessment of populations of Junniperus phoenica L. in the Al-Akhdar mountains landscape of Lybia. Arid Land Res. Manag. 2016, 30, 269-289. [CrossRef]

94. Barbache, A.; Beghami, Y.; Benmessaoud, H. Study and diachronic of forest cover changes of Belezma-Algeria. Geogr. Pannonica 2018, 22, 253-263. [CrossRef]

95. Touhami, I.; Chirino, E.; Aouinti, H.; El Khorchani, A.; Elaieb, M.T.; Khaldi, A.; Nasr, Z. Decline and dieback of cork oak (Quercus suber L.) forests in the Mediterranean basin: A case study of Kroumirie, Northwest Tunisia. J. For. Res. 2020, 31, $1461-1477$. [CrossRef]

96. Navarro-Cerillo, R.M.; Sarmoum, M.; Gazol, A.; Abdoum, F.; Camarero, J. The decline of Algerian Cedrus atlantica Forests is driven by a climate shifts towards drier conditions. Dendrochronologia 2019, 55, 60-70. [CrossRef]

97. Sarmoum, M.; Navarro-Cerrillo, R.; Guibal, F. Assessment of current and previous dieback of Atles cedars in Algeria's Theniet El Had National Park. Bois For. Des Trop. 2019, 342, 29-40.

98. Camarero, J.J.; Sanchez-Salguero, R.; Sanguesa-Barreda, G.; Lechuga, V.; Vinegla, B.; Seco, J.I.; Taiqui, L.; Carreira, J.A.; Linares, J.C. Drought, axe and goats. More variable and synchronized growth forecasts worsening dieback in Moroccan Atlas cedar forests. Sci. Total Environ. 2021, 765, 142752. [CrossRef]

99. Said, L.; Najib, G.; Assmaa, A. Towards a coordinated development of the forest in Maamora (Morocco). Kastamonu Uni. J. For. Facul. 2010, 10, 172-179. 
100. Linares, J.C.; Taiqui, L.; Camarero, J.J. Increasing drought sensitivity and decline of Atlas cedar (Cedrus atlántica) in the Moroccan meddle Atlas forests. Forests 2011, 2, 777-796. [CrossRef]

101. Chebli, Y.; Chentouf, M.; Ozer, P.; Hornick, J.L.; Cabaraux, J.F. Forest and silvopastoral cover changes and its drivers in northern Morocco. Appl. Geogr. 2018, 101, 23-35. [CrossRef]

102. Ruffault, J.; Curt, T.; Martin-StPaul, N.K.; Moron, V.; Trigo, R.M. Extreme wildfire events are linked to global-change-type droughts in the northern Mediterranean. Nat. Haz. Earth Syst. Sci. 2018, 18, 847-856. [CrossRef]

103. Sperlich, D.; Chang, C.T.; Peñuelas, J.; Gracia, C.; Sabate, S. Seasonal variability of foliar photosynthetic and morphological traits and drought impacts in a Mediterranean mixed forest. Tree Physiol. 2015, 35, 501-520. [CrossRef]

104. Camarero, J.J.; Sanguesa-Barreda, G.; Vergarechea, M. Prior height, growth, and Wood anatomy differently predispose to drought-induced dieback in two Mediterranean oak species. An. For Sci. 2016, 73, 341-351. [CrossRef]

105. Lloret, F.; Siscart, D.; Dalmases, C. Canopy recovery after drought dieback in holm-oak Mediterranean forest of Catalonia (NE Spain). Glob. Chang. Biol. 2004, 10, 2092-2099. [CrossRef]

106. Saura-Mas, S.; Bonas, A.; Lloret, F. Plant community response to drought-induced canopy defoliation in a Mediterranean Quercus ilex forest. Eur. J. For. Res. 2015, 134, 261-272. [CrossRef]

107. Pasho, E.; Camarero, J.J.; de Luis, M.; Vicente-Serrano, S.M. Factors driving growth responses to drought in Mediterranean forest. Eur. J. For. Res. 2012, 131, 1797-1807. [CrossRef]

108. Pasho, E.; Camarero, J.J.; de Luis, M.; Vicente-Serrano, M. Impacts of drought at different time scales on forest growth across a wide climatic gradient in north-eastern Spain. Agric. For. Meteorol. 2011, 151, 1800-1811. [CrossRef]

109. Granda, E.; Camarero, J.J.; Gimeno, T.E.; Martinez-Fernandez, J.; Valladares, F. Intensity and timing of warming and drought differently affect growth patterns of co-occuring Mediterranean tree species. Eur. J. For. Res. 2013, 132, 469-480. [CrossRef]

110. Bussotti, F.; Feducci, M.; Iacopetti, G.; Maggino, F.; Pollastrini, M.; Selvi, F. Linking forest diversity and tree health: Preliminary insights from a large-scale survey in Italy. For. Ecosyst. 2018, 5, 12. [CrossRef]

111. Forner, A.; Valladares, F.; Aranda, I. Mediterranean trees coping with severe drought: Avoidance might not be safe. Environ. Exp. Bot. 2018, 155, 529-540. [CrossRef]

112. Caminero, L.; Genova, M.; Camarero, J.J.; Sanchez-Salguero, R. Growth responses to climate and drought at the southernmost European limit of Mediterranean Pinus pinaster forest. Dendrochronologia 2018, 48, 20-29. [CrossRef]

113. De Marco, A.; Proietti, C.; Cionni, I.; Fischer, R.; Screpanti, A.; Vitale, M. Future impacts of nitrogen deposition and climate change scenarios on forest crown defoliation. Environ. Pollut. 2014, 194, 171-180. [CrossRef] [PubMed]

114. Peñuelas, J.; Filella, I.; Lloret, F.; Piñol, J.; Siscart, D. Effects of a severe drought on water and nitrogen use by Quercus ilex and Phillyrea latifolia. Biol. Plant. 2000, 43, 47-53. [CrossRef]

115. Rosas, T.; Galiano, L.; Ogaya, R.; Peñuelas, J.; Martínez-Vilalta, J. Dynamics of non-structural carbohydrates in three Mediterranean Woody species following long-term experimental drought. Front. Plant Sci. 2013, 4, 400. [CrossRef]

116. Sarris, D.; Koutsias, N. Ecological adaptations of plants to drought influencing the recent fire regime in the Mediterranean. Agric. For. Metereol. 2014, 184, 158-169. [CrossRef]

117. Doblas-Miranda, E.; Alonso, R.; Arnan, X.; Bermejo, V.; Brotons, L.; Heras, J.D.; Estiarte, M.; Hódar, J.A.; Llorens, P.; Lloret, F.; et al. A review of the combination among global change factors in forest, shrublands and pastures of the Mediterranean region: Beyond drought effects. Glob. Planet. Chang. 2017, 148, 42-54. [CrossRef]

118. Riedel, J.L.; Bernués, A.; Casasús, I. Livestock grazing impacts on herbage and shrub dynamics in a Mediterranean Natura Park. Rangel. Ecol. Manag. 2013, 66, 224-233. [CrossRef]

119. Rolo, V.; Moreno, G. Shrub encroachment and climate change increase the exposure to drought of Mediterranean wood-pastures. Sci. Total Environ. 2019, 660, 550-558. [CrossRef] [PubMed]

120. Serra-Maluquer, X.; Mencuccini, M.; Martinez-Vilalta, J. Changes in tree resistance, recovery and resilence across three successive extreme droughts in the northeast Iberian Peninsula. Oecologia 2018, 187, 343-354. [CrossRef] [PubMed]

121. Forner, A.; Valladares, F.; Bonal, D.; Granier, A.; Grossiord, C.; Aranda, I. Extreme droughts affecting Mediterranean tree species' growth and water-use efficiency: The importance of timing. Tree Physiol. 2018, 38, 1127-1137. [CrossRef]

122. Puletti, N.; Mattioli, W.; Bussotti, F.; Pollastrini, M. Monitoring the effects of extreme drought events on forest health by Sentinel-2 imagery. J. Appl. Rem. Sens. 2019, 13, 020501. [CrossRef]

123. Carus, S. Impact of defoliation by the pine processionary moth (Thaumetopoea pityocampa) on radial, height and volume growth of Calabrian pine (Pinus brutia) trees in Turkey. Phytoparasitica 2004, 32, 459-469. [CrossRef]

124. Mecheri, H.; Kouidri, M.; Boukheroufa-Sakraoui, F.; Adamou, A.E. Variation in Thaumetopoea pityocampa infestation rate of Aleppo pine: Effect on dendrometric parameters in the Djelfa region forest (Saharan Atlas, Algeria). Comptes Rendus Biol. 2018, 341, 380-386. [CrossRef]

125. Erkan, N. Five-year results of the impact of pine processionary moth (Thaumetopoea wilkinsoni Tams) on the growth of Turkish red pine (Pinus brutia Ten.). Turk. J. For. Res. 2018, 52, 135-142.

126. Avila, J.M.; Gallardo, A.; Ibañez, B.; Gomez-Aparicio, L. Quercus suber dieback alters soil respiration and nutrient availability in Mediterranean forest. J. Ecol. 2016, 104, 1441-1452. [CrossRef]

127. Frisullo, S.; Lima, G.; di San Lio, G.M.; Camele, I.; Melissano, L.; Puglisi, I.; Pane, A.; Agosteo, G.E.; Prudente, L.; Cacciola, S.O. Phytophthora cinnamomi involved in the decline of holm oak (Quercus ilex) stands in Southern Italy. For. Sci. 2018, 64, 290-298. [CrossRef] 
128. Rodriguez-Molina, M.C.; Torres-Vila, L.M.; Blanco-Santos, A.; Nunez, E.J.P.; Torres-Alvarez, E. Viability of holm and cork oak seedlings from acorns sown in Soils naturally infected with Phytophthora cinnamomi. For. Pathol. 2002, 32, 365-372. [CrossRef]

129. Brasier, C.M.; Scott, J.K. European oak declines and global warming: A theoretical assessment with special reference to the activity of Phytophthora cinnamomi. Bull. OEPP 1994, 24, 221-232. [CrossRef]

130. Camilo-Alves, C.D.E.P.; da Clara, M.I.E.; Ribeiro, N.M.C.D. Decline of Mediterranean oak trees and its association with Phytophthora cinnamomi: A review. Eur. J. For. Res. 2013, 132, 411-432. [CrossRef]

131. Martin-Garcia, J.; Solla, A.; Corcobado, T.; Siasou, E.; Woodward, S. Influence of temperatura on germination of Quercus ilex in Phytophthora cinnamomi, P. gonapodyides, P. quercina and P. psychrophila infested soils. For. Pathol. 2015, 45, 215-223. [CrossRef]

132. Ajchler, M.; Lobocka, M.; Oszako, T. Pathogenic oomycetes of Phytophthora genus-A new threat to forest in Europe. Sylwan 2017, $161,870-880$.

133. Hernandez-Lambrano, R.E.; Gonzalez-Moreno, P.; Sanchez-Agudo, J.A. Environmental factors associated with the spatial distribution of invasive plant pathogens in the Iberian Peninsula: The case of Phytophthora cinnamomi Rands. For. Ecol. Manag. 2018, 419, 101-109. [CrossRef]

134. Solla, A.; Garcia, L.; Perez, A.; Cordero, A.; Cubera, E.; Moreno, G. Evaluating potassium phosphonate injections for the control of Quercus ilex decline in SW Spain: Implications of low soil contamination by Phytophthora cinnamomi and low soil water content on the effectiveness of treatments. Phytoparasitica 2009, 37, 303-316. [CrossRef]

135. Bergot, M.; Cloppet, E.; Perarnaud, V.; Deque, M.; Marcais, B.; Desprez-Loustau, M.L. Simulation of potential range expansion of oak disease caused by Phytophthora cinnamomi under climate change. Glob. Chang. Biol. 2004, 10, 1539-1552. [CrossRef]

136. Marcais, B.; Bergot, M.; Perarnaud, V.; Levy, A.; Desprez-Loustau, M.L. Prediction and mapping of the impact of winter temperature on the development of Phytophthora cinnamomi-induced cankers on red pedunculate oak in France. Phytopathology 2004, 94, 826-831. [CrossRef] [PubMed]

137. Fernandez-Habas, J.; Fernandez-Rebollo, P.; Casado, M.R.; Moreno, A.M.G.; Abellanas, B. Spatio-temporal analysis of oak decline process in open woodlands: A case study in SW Spain. J. Envron. Manag. 2019, 248, 109308. [CrossRef]

138. Gallardo, A.; Morcuende, D.; Solla, A.; Moreno, G.; Pulido, F.; Quesada, A. Regulation by biotic stress of tannins biosynthesis in Quercus ilex: Crosstalk between defoliation and Phytophthora cinnamomi infection. Physiol. Plant. 2019, 165, 319-329. [CrossRef]

139. Sena, K.; Crocker, E.; Vincelli, P.; Barton, C. Phytophthora cinnamomi as a driver of forest change: Implications for conservation and management. For. Ecol. Manag. 2018, 409, 799-807. [CrossRef]

140. Jimenez-Chacon, A.; Homet, P.; Matias, L.; Gomez-Aparicio, L.; Godoy, O. Fine scale determinants of soil litter fauna on a Mediterranean mixed oak forest invaded by the exotic soil-borne Pathogen Phytophthora cinnamomi. Forests 2018, 9, 218. [CrossRef]

141. Gomez-Aparicio, L.; Ibañez, B.; Serrano, M.S.; De Vita, P.; Avila, J.M.; Perez-Ramos, J.M.; García, L.V.; Sánchez, M.E.; Marañon, T. Spatial patterns of soil pathogens in declining Mediterranean forest: Implications for tree species regeneration. New Phytol. 2012, 194, 1014-1024. [CrossRef]

142. Moralejo, E.; Garcia-Muñoz, J.A.; Descals, E. Susceptibility of Iberian trees to Phytophthora ramorum and P. cinnamomi. Plant Pathol. 2009, 58, 271-283. [CrossRef]

143. Gea-Izquierdo, G.; Viguera, B.; Cabrera, M.; Canellas, I. Drought induced decline could portend widespread pine mortality at the xeric ecotone in managed mediterranean pine-oak woodlands. For. Ecol. Manag. 2014, 320, 70-82. [CrossRef]

144. Moreira, A.C.; Tapias, R.; Fernandes, L. Field susceptibility of cork oak trees with different provenances to Phytophthora cinnamomi. For. Pathol. 2018, 48, 12461. [CrossRef]

145. Serrano, M.S.; Fernandez-Rebollo, P.; De Vita, P.; Sanchez, M.E. Susceptibility of common herbaceous crops to Phytophthora cinnamomi and its influence on Quercus root in rangelands. Eur. J. Plant Pathol. 2012, 134, 409-414. [CrossRef]

146. Davi, H.; Durand-Gillmann, M.; Damesin, C.; Delzon, S.; Petit, C.; Rozenberg, P.; Sabatier, S.A.; Chadoeuf, J.; Boutte, B.; Boivin, T. Distribution of endemic bark beetle attacks and their physiological consequences on Pinus halepensis. For. Ecol. Manag. 2020, 469, 118187. [CrossRef]

147. Beghami, R.; Bertella, N.; Laameri, M.; Bensaci, O.A. Bark beetle and woodborer insects' outbreaks as a potent driver of Atlas cedar (Cedrus atlantica (Endl.)) Carriere) forests dieback in Aures-East Algeria. For. Sci. Technol. 2020, 16, 75-85. [CrossRef]

148. Sanguesa-Barreda, G.; Camarero, J.J.; Garcia-Martin, A.; Hernandez, R.; de la Riva, J. Remote-sensing and tree-ring based characterization of forest defoliation and growth loss due to the Mediterranean pine processionary moth. For. Ecol. Manag. 2014, 320, 171-181. [CrossRef]

149. Pernek, M.; Lackovic, N.; Lukic, I.; Zoric, N.; Matosevic, D. Outbreak of Orthotomicus erosus (Coleoptera cucrulionedae) on Aleppo pine in the Mediterranean region in Croatia. Seefor-South-East Eur. For. 2019, 10, 19-27. [CrossRef]

150. Klein, T.; Cahanovitc, R.; Sprintsin, M.; Herr, N.; Schiller, C. A nation-wide analysis of tree mortality under climate change: Forest loss and its causes in Israel 1948-2017. For. Ecol. Manag. 2019, 432, 840-849. [CrossRef]

151. Rivas-Ubach, A.; Sardans, J.; Hódar, J.A.; Garcia-Porta, J.; Guenther, A.; Paša-Tolić, L.; Oravec, M.; Urban, O.; Peñuelas, J. Close and distant: Contrasting the metabolism of two closely related subspecies of Scots pine under the effects of folivory and summer drought. Ecol. Evol. 2017, 7, 8976-8988, Dorad. [CrossRef]

152. Panzavolta, T.; Panichi, A.; Bracalini, M.; Croci, F.; Ginetti, B.; Ragazzi, A.; Tiberi, R.; Morica, S. Dispersal and propagule pressure of Botryosphaeriacaceae species in a declining oak stand is affected by insect vectors. Forests 2017, 8, 228. [CrossRef]

153. Ertugrul, M.; Varol, T.; Kaygin, A.T.; Ozel, H.B. The relationships between climate change and forest disturbances in Turkey. Fres. Environ. But. 2017, 26, 4064-4074. 
154. Colombari, F.; Battisti, A.; Schroeder, L.M.; Faccoli, M. Life-history promoting outbreaks of the pine bark beetle Ips acuminatus (Coleoptera: Curculionidae scolytinae) in the south-eastern Apls. Eur. J. For. Res. 2012, 131, 553-561. [CrossRef]

155. Mahamedi, A.E.; Phillips, A.J.L.; Lopes, A.; Djellid, Y.; Arkam, M.; Eichmeier, A.; Zitouni, A.; Alves, A.; Berraf-Tebbal, A. Diversity, distribution and host association of Botryosphaeriaceaes species causing oak decline across different forest ecosystems in Algeria. Eur. J. Plant Pathol. 2020, 158, 745-765. [CrossRef]

156. Ghaioule, D.; Lumaret, J.P.; Rochat, D.; Maatouf, N.; Niogret, J. Estimation of white grub damage (Coleoptera: Scarabaeoidea) in cork oak (Quercus suber L.) regeneration parcels of the mamora forest (Morocco) and search for biological control using sex pheromones. An. Soc. Entomol. Fr. 2007, 43, 1-8. [CrossRef]

157. El Abidine, A.Z. Forest decline in Morocco: Causes and control strategy. Secheresse 2003, 14, $209-218$.

158. Ghjalem, A.; Barbosa, I.; Bouhraoua, R.T.; Costa, A. Climate signal in cork-ring chronosequences: Case studies in southwestern Portugal and Northwestern Algeria. Tree-Ring Res. 2018, 74, 15-27. [CrossRef]

159. Navarro-Cerrillo, R.M.; Manzanedo, R.D.; Rodriguez-Vallejo, C.; Gazol, A.; Palacios-Rodriguez, G.; Camarero, J.J. Competition modulates the response of growth to climate in pure and mixed Abies pinsapo subsp. Maroccana forests in northern Marocco. For. Ecol. Manag. 2020, 459, 117847. [CrossRef]

160. De Waroux, Y.L.; Lambin, E.F. Monitoring degradation in arid and semi-arid forests and woodlands: The case of the argan woodlands (Morocco). Appl. Geogr. 2012, 32, 777-786. [CrossRef]

161. Sebbar., B.; Moumni, A.; Lahrouni, A.; Chehbouni, A.; Belghazi, T.; Maksoudi, B. Remotely sensed phenology monitoring and Land-cover classification for the localization of the endemic argan tree in the southern-west of Morocco. J. Sust. For. 2021. [CrossRef]

162. Mahojane, M.; Essahlaoui, A.; Oudija, F.; El Hafyani, M.; El Hmaidi, A.; El Ouali, A.; Randazzo, G.; Teodoro, A.C. Land use/land cover (LULC) using landsat data series (MSS, TM, ETM+ and OLI) in Azrou F0rest, in the central middle Atlas of Marocco. Environments 2018, 5, 131. [CrossRef]

163. Camarero, J.J.; Manzanedo, R.D.; Sanchez-Salguero, R.; Navarro-Cerillo, R.M. Growth response to climate and drought change along an aridity gradient in the southernmost Pinus nigra relict forests. An. For. Sci. 2013, 70, 769-780. [CrossRef]

164. Barba, J.; Yuste, J.C.; Martínez-Vilalta, J.; Lloret, F. Drought-induced tree species replacement is reflected in the spatial variability of soil respiration in a mixed Mediterranean forest. For. Ecol. Manag. 2013, 306, 79-87. [CrossRef]

165. Helman, D.; Lensky, I.M.; Yakir, D.; Osem, Y. Forest growing under dry conditions have higher hydrological resilence to drought than do more humid forest. Glob. Chang. Biol. 2017, 23, 2801-2817. [CrossRef]

166. Tegel, W.; Seim, A.; Hakelberg, D.; Hoffmann, S.; Panev, M.; Westphal, T.; Büntgen, U. A recent growth increase of European beech (Fagus sylvatica L.) at its Mediterranean distribution limit contradicts drought stress. Eur. J. For. Res. 2014, 133, 61-71. [CrossRef]

167. Azuara, J.; Lebreton, V.; Peyron, O.; Mazier, F.; Combourieu-Nebout, N. The Holocene history of low altitude Mediterranean Fagus sylvatica forests in southern France. J. Veg. Sci. 2018, 29, 438-449. [CrossRef]

168. Castro, J.; Zamora, R.; Hodar, J.A.; Gomez, J.M. Alleviation of summer drought boosts establishment success of Pinus sylvestris in a Mediterranean mountain: An experimental approach. Plant Ecol. 2005, 181, 191-202. [CrossRef]

169. Galiano, L.; Martínez-Vilalta, J.; Lloret, F. Drought induced multifactor decline of scots pine in the Pyrenees and potential vegetation change by the expansion of co-occurring oak species. Ecosystems 2010, 13, 978-991. [CrossRef]

170. Sanchez-Salguero, R.; Navarro-Cerrillo, R.M.; Swetnam, T.W.; Zavala, M.A. Is drought the main decline factor al the rear edge of Europe? The case of southern Iberian pine plantations. For. Ecol. Manag. 2012, 271, 158-169. [CrossRef]

171. Sanchez-Salguero, R.; Navarro-Cerrillo, R.M.; Camarero, J.J.; Fernandez-Cancio, A. Selective drought-induced decline of pin species in southeastern Spain. Selective drought-induced decline of pine species in southeastern Spain. Clim. Chang. 2012, 113, 767-785. [CrossRef]

172. Poyatos, R.; Aguade, D.; Galiano, L.; Mencuccini, M.; Martinez-Vilalta, J. Drought-induced defoliation and long periods of near-zero gas Exchange play a key role in accentuating metabolic decline of Scots pine. New Phytol. 2013, 200, 388-401. [CrossRef]

173. Shestakova, T.A.; Camarero, J.J.; Ferrio, J.P.; Knorre, A.A.; Gutierrez, E.; Voltas, J. Increasing drought effects on five European pines modulate Delta C-13 growth coupling along a Mediterranean altitudinal gradient. Funct. Ecol. 2017, 31, 1359-1370. [CrossRef]

174. Vila-Abrera, A.; Jump, A.S. Greater growth stability of tres in marginal habitasts suggests a patchy pattern of population loss and retention in response to increased drought at the rear edge. Ecol. Lett. 2019, 22, 1439-1449. [CrossRef]

175. Kefauver, S.C.; Peñuelas, J.; Ustin, S.L. Improving assessments of tropospheric ozone injury to Mediterranean montane conifer forest in California (USA) and Catalonia (Spain) with GIS models related to plant water relations. Atm. Environ. 2012, 62, 41-49. [CrossRef]

176. Herrero, A.; Zamora, R.; Castro, J.; Hodar, J.A. Limits of pine forest distribution at the treeline: Herbivory matters. Plant Ecol. 2012, 213, 459-469. [CrossRef]

177. Vilà, M.; Pino, J.; Font, X. Regional assessment of plant invasions across different habitat types. J. Veget. Sci. 2007, 18, 35-42. [CrossRef]

178. Chytrý, M.; Maskell, L.C.; Pino, J.; Pyšek, P.; Vilà, M.; Font, X.; Smart, S.M. Habitat invasions by alien plants: A quantitative comparison among Mediterranean, subcontinental and oceanic regions of Europe. J. Appl. Ecol. 2008, 45, 448-458. [CrossRef]

179. Clotet, M.; Basnou, C.; Bagaria, G.; Pino, J. Contrasting historical and current land-use correlation with diverse components of current alien plant invasions in Mediterranean habitats. Biol. Invasions 2016, 18, 2897-2909. [CrossRef] 
180. Pino, J.; Arnan, X.; Rodrigo, A.; Retana, J. Post-fire invasion and subsequent extinction of Conyza spp. in Mediterranean forests is mostly explained by local factors. Weed Res. 2013, 53, 470-478. [CrossRef]

181. Erskine-Ogden, J.; Grotkopp, E.; Rejmanek, M. Mediterranean, invasive, woody species grow larger than their less-invasive counterparts under potential global environmental change. Am. J. Bot. 2016, 103, 613-624. [CrossRef]

182. Nunes, L.J.R.; Meireles, C.I.R.; Pinto Gomes, C.J.; Ribeiro, N.M.C.A. Historical development of the Portuguese forest: The introduction of invasive species. Forest 2019, 10, 974. [CrossRef]

183. Arianoutsou, M.; Vila, M. Black locust increased C and N stocks in the upper organic layers that are more vulnerable to disturbance. However, it did not increase N stocks in the mineral soil. Fire and Invasive Plant Species in the Mediterranean Basin. Isr. J. Ecol. Evol. 2012, 58, 195-203.

184. Moreira, F.; Ferreira, A.; Abrantes, N.; Catry, F.; Fernandes, P.; Roxo, L.; Keizer, J.J.; Silva, J.S. Occurrence of native and exotic invasive trees in burned pine and eucaliptus plantations: Implications for post-fire forest conversión. Ecol. Engin. 2013, 58, 296-302. [CrossRef]

185. Fernandes, P.; Antunes, C.; Correira, O.; Maguas, C. Do climatic and habitat conditions affect the reproductive success of an invasive tree species? An assessment of the phenology of Acacia longifolia in Portugal. Plant Ecol. 2015, 216, 343-355. [CrossRef]

186. Godoy, O.; de Lemos, J.P.; Valladares, F. Invasive species can handle higher leaf temperatura under wáter stress than Mediterranean natives. Environ. Exp. Bot. 2011, 71, 207-214. [CrossRef]

187. Gonzalez-Moreno, P.; Pino, J.; Gasso, N.; Vila, M. Landscape context modulates alien plant invasion in Mediterranean forest edges. Biol. Invasions 2013, 15, 547-557. [CrossRef]

188. Cabra-Rivas, I.; Alonso, A.; Castro-Diez, P. Does stream structure affect dispersal by water? A case study of the invasive tree Ailanthus altissima in Spain. Manag. Biol. Invasions 2014, 5, 179-186. [CrossRef]

189. Medina-Villar, S.; Castro-Diez, P.; Alonso, A.; Cabra-Rivas, I.; Parker, I.M.; Perez-Corona, E. Do the invasive trees, Ailanthus altissima and Robinia pseudoacacia, alter litterfall dynamics and soil properties of riparian ecosystems in Central Spain? Plant Soil 2015, 396, 311-324. [CrossRef]

190. Idzojtic, M.; Zebec, M. Distribution of the tree of heaven (Ailanthus altissima/Mill./Swingle) and spreading of invasive woody alien species in Croatia. Clasniz Sumske Pokuse 2006, 5, 315-323.

191. De Marco, A.; Arena, C.; Giordano, M.; De Santo, A. Impact of the invasive tree black locus ton soil properties of Mediterranean Stone pine-holm oak forests. Plant Soil 2013, 372, 473-486. [CrossRef]

192. Castro-Diez, P.; Gonzalez-Munoz, N.; Alonso, A.; Gallardo, A.; Poorter, L. Effects of exotic invasive trees on nitrogen cycling: A case study in Central Spain. Biol. Invasions 2009, 11, 1973-1986. [CrossRef]

193. Ouadah, N.; Kadik, L.; Bendjedda, N.; Kaabechekl, M. Impact of fire on the regeneration strategy of Mediterranean forest plant species. The present study was carried out in the Chrea National Park (Algeria). Rev. Ecol. Terre Vie 2016, 71, 356-366.

194. Riva, M.J.; Liniger, H.; Valdecantos, A.; Schwilch, G. Impacts of land Management on the resilence of Mediterranean dry forest to fire. Sustainability 2016, 8, 981. [CrossRef]

195. Raftoyannis, Y.; Nocentini, S.; Marchi, E.; Sainz, R.C.; Guemes, C.G.; Pilas, I.; Peric, S.; Paulo, J.A.; Moreira-Marcelino, A.C.; Costa-Ferreira, M.; et al. Perceptions of forest experts on climate change and fire management in European Mediterranean forests. iFor. Biogeosci. For. 2013, 7, 33-41. [CrossRef]

196. Moreira, F.; Viedma, O.; Arianoutsou, M.; Curt, T.; Koutsias, N.; Rigolot, E.; Barbati, A.; Corona, P.; Vaz, P.; Xanthopoulos, G.; et al. Landscape-wildfire interactions in southern Europe: Implications for landscape management. J. Environ. Manag. 2011, 92, 2389-2402. [CrossRef] [PubMed]

197. Ruffault, J.; Mouillot, F. Contribution of human and biophysical factors to the spatial distribution of forest fire ignitions and large wildfires in a French Mediterranean region. Intern. J. Wildland Fire 2017, 26, 498-508. [CrossRef]

198. Madrigal, J.; Fernandez-Miguelanez, I.; Hernando, C.; Guijarro, M.; Vega-Nieva, D.J.; Tolosana, E. Does forest biomass harvesting for energy reduce fire hazard in the Mediterranean basin? A case study in the Caroig Massif (Eastern Spain). Eur. J. For. Res. 2017, 136, 13-26. [CrossRef]

199. Ursino, N.; Romano, N. Wild forest fire regime following land abandonment in the Mediterranean region. Geophys. Res. Lett. 2014, 41, 8359-8368. [CrossRef]

200. Stamou, Z.; Xystrakis, F.; Koutsias, N. The role of fire as a long-term landscape modifier: Evidence from long-term fire observations (1922-2000) in Greece. Appl. Geogr. 2016, 74, 47-55. [CrossRef]

201. Fyllas, N.M.; Troumbis, A.Y. Simulating vegetation shifts in north-eastern Mediterranean mountain forest under climatic change scenarios. Glob. Ecol. Biogeogr. 2009, 18, 64-77. [CrossRef]

202. Turco, M.; Levin, N.; Tessler, N.; Saaroni, H. Recent changes and relations among drought, vegetation and wildfires in the Eastern Mediterranean: The case of Israel. Glob. Planet. Chang. 2017, 151, 28-35. [CrossRef]

203. Batllori, E.; De Caceres, M.; Brotons, L.; Ackerly, D.D.; Moritz, M.A.; Lloret, F. Cumulative effects of fire and drought in Mediterranean ecosystems. Ecosphere 2017, 8, e01906. [CrossRef]

204. Turco, M.; Rosa-Cánovas, J.J.; Bedia, J.; Jerez, S.; Montávez, J.P.; Llasat, M.C.; Provenzale, A. Exacerbated fires in Mediterranean Europe due to anthropogenic warming projected with non-stacionary climate-fire models. Nat. Com. 2018, 9, 3821. [CrossRef]

205. Hinojosa, M.B.; Parra, A.; Ramirez, D.A.; Carreira, J.A.; Garcia-Ruiz, R.; Moreno, J.M. Effects of drought on soil phosphorus availability and fluxes in a burned Mediterranean shrubland. Geoderma 2012, 191, 61-69. [CrossRef] 
206. Hinojosa, M.B.; Parra, A.; Laudicina, V.A.; Moreno, J.M. Post-fire soil functionality and microbial community structure in a Mediterranean shrubland subjected to experimental drought. Sci. Total Environ. 2016, 573, 1178-1189. [CrossRef] [PubMed]

207. Hinojosa, M.B.; Laudicina, V.A.; Parra, A.; Albert-Belda, E.; Moreno, J.M. Drought and its legacy modulate the post-fire recovery of soil functionality and microbial community structure in a Mediterranean shrubland. Glob. Chang. Biol. 2019, 25, $1409-1427$. [CrossRef] [PubMed]

208. Baudena, M.; Santana, V.; Baeza, M.J.; Bautista, S.; Eppinga, M.B.; Hemerik, L.; Garcia Mayor, A.; Rodriguez, F.; Valdecantos, A.; Vallejo, V.R.; et al. Increased aridity drives post-fire of Mediterranean forests towards open shrublands. New Phytol. 2020, 225, 1500-1515. [CrossRef]

209. Baeza, M.J.; Valdecantos, A.; Alloza, J.A.; Vallejo, V.R. Human disturbance and Environmental factors as drivers of long-term post-fire regeneration pattern in Mediterranean forest. J. Veg. Sci. 2007, 18, 243-252. [CrossRef]

210. Tessler, N.; Wittenberg, L.; Greenbaum, N. Vegetation cover and species richness after recurrent forest fires in the Eastern Mediterranean ecosystem of Mount Carmel, Israel. Sci. Total Environ. 2016, 572, 1395-1402. [CrossRef]

211. Varol, T.; Ertugrul, M. Climate change and forest fire trend in the Aegean and Mediterranean regions of Turkey. Fres. Environ. Bull. 2015, 24, 3436-3444.

212. Karavani, A.; Boer, M.M.; Baudena, M.; Colinas, C.; Diaz-Sierra, R.; Peman, J.; de Luis, M.; Enriquez-de-Salamanca, A. Fireinduced deforestation in drought-prone Mediterranean forestrs: Drivers and unknows from leaves to communities. Ecol. Monogr. 2018, 88, 141-169. [CrossRef]

213. Vieira, D.C.S.; Malvar, M.C.; Fernandez, C.; Serpa, D.; Keizer, J.J. Annual runoff and erosion in a recently burn Mediterranean forest-The effects of plowing and time-since-fire. Geomorphology 2016, 270, 172-180. [CrossRef]

214. Gomez-Sanchez, E.; Lucas-Borja, M.E.; Plaza-Alvarez, P.A.; Gonzalez-Romero, J.; Sagra, J.; Moya, D.; De Las Heras, J. Effects of post-fire hillslope stabilisation techniques on chemical, physicochemical and microbiological soil properties in Mediterranean forest ecosystems. J. Environ. Manag. 2019, 246, 229-238. [CrossRef]

215. Knicker, H.; Gonzalez-Vila, F.J.; Polvillo, O.; Gonzalez, J.A.; Almendros, G. Fire-induced transformation of C- and N-forms in different organic soil fractions from a dystric cambisol under a Mediterranean pine forest (Pinus pinaster). Soil Biol. Biochem. 2005, 37, 701-718. [CrossRef]

216. Ubeda, X.; Bernia, S.; Simelton, E. The long-term effects on soil properties from a forest fire of varying intensity in a Mediterranean environment. Catchment Dynamics and River Processes: Mediterranean and other Climate Regions. Edited by: Garcia C, Batalla RJ. Book Series: Develop. Earth Surf. Proses. 2005, 7, 87-102.

217. Alcaniz, M.; Outeiro, L.; Francos, M.; Farguell, J.; Ubeda, X. Long-term dynamics of soil chemical properties after a prescribed fire in a Mediterranean forest (Montgri Massif, Catalonia, Spain). Sci. Total Environ. 2016, 572, 1329-1335. [CrossRef]

218. Garcia-Llamas, P.; Suarez-Seoane, S.; Taboada, A.; Fernandez-Manso, A.; Quintano, C.; Fernandez-Garia, V.; Fernandez-Guisuraga, J.M.; Marcos, E.; Calvo, L. Environmental drivers of fire severity in extreme fire events that affect Mediterranean pine forest ecosystems. For. Ecol. Manag. 2019, 433, 24-32. [CrossRef]

219. Bedia, J.; Herrera, S.; Camia, A.; Moreno, J.M.; Gutierrez, J.M. Forest fire danger projections in the Mediterranean using ENSEMBLES regional climate change scenarios. Clim. Chang. 2014, 122, 185-199. [CrossRef]

220. Varela, M.E.; Benito, E.; Keizer, J.J. Influence of wildfire severity on soil physical degradation in two pine forest stands of NW Spain. Catena 2015, 133, 342-348. [CrossRef]

221. Varela, V.; Vlachogiannis, D.; Sfetsos, A.; Karozis, S.; Politi, N.; Giroud, F. Projection of forest fire danger due to climate change in the French Mediterranean region. Sustainability 2019, 16, 4284. [CrossRef]

222. Coello, J.; Ameztegui, A.; Rovira, P.; Fuentes, C.; Pique, M. Innovative soil conditioners and mulches forest restoration in semiarid conditions in northeast Spain. Ecol. Eng. 2018, 118, 52-65. [CrossRef]

223. Cangir, C.; Boyraz, D. Climate change and impact of desertification or soil/(land degradation in Turkey, combating desertification. J. Tekirdag Agricul. Fac. 2008, 5, 169-186.

224. Laouina, A.; Aderghal, M.; Al Karkouri, J.; Antari, M.; Chacker, M.; Laghazi, Y.; Machmachi, J.; Machouri, N.; Nafaa, R.; Naimi, K.; et al. The efforts for cork oak forest management and their effects on soil conservation. For. Syst. 2010, 19, 263-277. [CrossRef]

225. Madeira, M. Thirty years of research on soil quality in forest systems under Mediterranean conditions. Trends and future. Span. J. Soil Sci. 2015, 5, 98-110.

226. Salvati, L.; Kosmas, C.; Kairis, O.; Karavitis, C.; Acikalin, S.; Belgacem, A.; Sole-Benet, A.; Chaker, M.; Fassouli, V.; Gokceoglu, C.; et al. Unveiling soil degradation and desertification risk in the Mediterranean basin: A data mining analysis of the relationships between biophysical and socioeconomic factors in agro-forest landscapes. J. Environ. Plan. Manag. 2015, 58, 1789-1803. [CrossRef]

227. Ozalp, M.; Yuksel, E.E.; Yuksek, T. Soil property changes after conversion from forest to pasture in Mount Sacinka, Artvin, Turkey. Land Degrad. Develop. 2016, 27, 1007-1017. [CrossRef]

228. Kairis, O.; Karavitis, C.; Salvati, L.; Kounalaki, A.; Kosmas, K. Exploring the impact of overgrazing on soil erosion and land degradation in a dry Mediterranean agro-forest landscape. Arid Land Res. Manag. 2015, 29, 360-374. [CrossRef]

229. Salvati, L.; Carlucci, M. Towards sustainability in agro-forest systems? Grazing intensity, soil degradatrion and the socioeconomic profile of rural communities in Italy. Ecol. Econom. 2015, 112, 1-13. [CrossRef]

230. Jimenez, M.N.; Fernandez-Ondono, E.; Ripoll, M.A.; Castro-Rodriguez, J.; Huntsinger, L.; Navarro, F.B. Stones and organic mulches improve Quercus ilex L. afforestation success under Mediterranean climatis conditions. Land Degrad. Develop. 2016, 27, 357-365. [CrossRef] 
231. Guenon, R.; Gros, R. Soil microbial functions after forest fires affrected by the compost quality. Land Degrad. Develop. 2016, 27, 1391-1402. [CrossRef]

232. Badia, D.; Marti, C. Fire and rainfall energy on soil erosion and runoff generation in semi-arid forested lands. Arid Land Res. Manag. 2008, 22, 93-108. [CrossRef]

233. Salvati, L.; Sabbi, A.; Smiraglia, D.; Zitti, M. Does forest expansion mitigate the risk of desertification? Exploring soil degradation and land-use changes in a Mediterranean country. Inter. For. Rev. 2014, 16, 485-496. [CrossRef]

234. Andres-Abellan, M.; Wic-Baena, C.; Lopez-Serrano, F.R.; García-Morote, F.A.; Martinez-García, E.; Picazo, M.I.; Rubio, E.; Moreno-Ortego, J.L.; Bastida-Lopez, F.; Garcia-Izquierdo, C. A soil-quality index for soil from Mediterranean forests. Eur. J. Soil Sci. 2019, 70, 1001-1011. [CrossRef]

235. Perez-Izquierdo, L.; Saint-Andre, L.; Santenoise, P.; Buee, M.; Rincon, A. Tree genotype and seasonal effects on soil properties and biogeochemical functioning in Mediterranean pine forests. Eur. J. Soil Sci. 2018, 69, 1087-1097. [CrossRef]

236. Médail, F.; Quézel, P. Biodiversity hotspots in the Mediterranean basin: Setting global conservation priorities. Conserv. Biol. 2001, 13, 1510-1513. [CrossRef]

237. Infusino, M.; Greco, S.; Turco, R.; Bernardini, V.; Scalercio, S. Managed mountain forest as diversity reservoirs in Mediterranean landscapes: New data on endemic species and faunistic novelties of moths. Bull. Insectol. 2016, 69, $249-258$.

238. Médail, F.; Monnet, A.C.; Pavon, D.; Nikolic, T.; Dimopoulos, P.; Bacchetta, G.; Arroyo, J.; Barina, Z.; Albassatneh, M.C.; Domina, G.; et al. What is a tree in the Mediterranean basin hotspot? A critical analysis. For. Ecosys. 2019, 6, 17. [CrossRef]

239. Gauquelin, T.; Michon, G.; Joffre, R.; Duponnois, R.; Genin, D.; Fady, B.; Dagher-Kharrat, M.B.; Derrigj, A.; Slimani, S.; Badri, W.; et al. Mediterranean forests, land use and climate change: A social-ecological perspective. Reg. Environ. Chang. 2018, 18, 623-636. [CrossRef]

240. Santoja, M.; Foucault, Q.; Rancon, A.; Gauquelin, T.; Fernandez, C.; Baldy, V.; Mirleau, P. Contrasting responses of bacterial and fungal communications to plant litter diversity in a Mediterranean oak forest. Soil Biol. Biochem. 2018, 125, 27-36. [CrossRef]

241. Bevivino, A.; Paganin, P.; Bacci, G.; Florio, A.; Pellicer, M.S.; Papaleo, M.C.; Mengoni, A.; Ledda, L.; Fani, R.; Benedetti, A.; et al. Soil Bacterial Community Response to Differences in Agricultural Management along with Seasonal Changes in a Mediterranean Region. PLoS ONE 2014, 9, e105515. [CrossRef]

242. Lladó, S.; López-Mondéjar, R.; Baldrian, P. Forest soil bacteria: Diversity, involvement in ecosystem processes, and response to global change. Microbiol. Mol Biol. Rev. 2017, 8, e00063-16. [CrossRef] [PubMed]

243. Chen, C.; Chen, H.Y.H.; Chen, X.; Huang, Z. Meta-analysis shows positive effects of plant diversity on microbial biomass and respiration. Nat. Com. 2019, 10, 1332. [CrossRef] [PubMed]

244. Oria-de-Rueda, J.A.; Hernandez-Rodriguez, M.; Martin-Pinto, P.; Pando, V.; Olaizola, J. Could artificial reforestation provide as much production and diversity of fungal species as natural forest stands in marginal Mediterranean áreas? For. Ecol. Manag. 2010, 260, 171-180. [CrossRef]

245. Buscardo, E.; Freitas, H.; Pereira, J.S.; De Angelis, P. Common Environmental factors explain both ectomycorrhizal species diversity and pine regeneration variability in a post-fire Mediterranean forest. Mycorrhiza 2011, 21, 549-558. [CrossRef] [PubMed]

246. Aragon, G.; Martinez, I.; Izquierdo, P.; Belinchon, R.; Escudero, A. Effects of forest Management on epiphytic lichen diversity in Mediterranean forests. Appl. Veg. Sci. 2010, 13, 183-194. [CrossRef]

247. Quinto, J.; Micó, E.; Martínez-Falcón, A.P.; Galante, E.; Marcos-García, M.A. Influence of tree hollow characteristics on the diversity of saproxylic insect guilds in Iberian Mediterranean woodlands. J. Insect Cons. 2014, 18, 981-992. [CrossRef]

248. Herrera, J.M.; Salgueiro, P.A.; Medinas, D.; Costa, P.; Encarnacao, C.; Mira, A. Generalities of vertebrate responses to landscape composition and configuration gradients in a highly heterogeneous Mediterranean región. J. Biogeog. 2016, 43, 1203-1214. [CrossRef]

249. Rodriguez, J.; Gonzalez-Perez, J.A.; Turmero, A.; Hernandez, M.; Ball, A.S.; Gonzalez-Vila, F.J.; Aria, M.E. Wildfire effects on the microbial activity and diversity in a Mediterranean forest soil. Catena 2017, 158, 82-88. [CrossRef]

250. Lazarina, M.; Devalez, J.; Neokosmidis, L.; Sgardelis, S.P.; Kallimanis, A.S.; Tscheulin, T.; Tsalkatis, P.; Kourtidou, M.; Mizerakis, P.; Nakas, G.; et al. Moderate fire severity is best for the diversity of most of the pollinator guilds in Mediterranean pine forests. Ecology 2019, 100, e02615. [CrossRef]

251. Nascimiento, E.; Reis, F.; Chichorro, F.; Canhoto, C.; Gonçalbves, A.L.; Simoes, S.; Sousa, J.P.; da Silva, P.M. Effects of Management on plant litter and consequences for litter mass loss Collembola functional diversity in a Mediterranean agro-forest system. Pedobiologia 2019, 75, 38-51. [CrossRef]

252. Selvi, F.; Carrari, E.; Coppi, A. Impact of pine invasión on the taxonomic and phylogenetic diversity of a relict Mediterranean forest ecosystem. For. Ecol. Manag. 2016, 367, 1-11. [CrossRef]

253. Kouba, Y.; Martinez-Garcia, F.; de Frutos, A.; Alados, C.L. Effects of previous land-use on plant species composition and diversity in Mediterranean forest. PLoS ONE 2015, 10, e0139031. [CrossRef] [PubMed]

254. Alvarez, R.; Muñoz, A.; Pesqueira, X.M.; Garcia-Duro, J.; Reyes, O.; Casal, M. Spatial and temporal patterns in structure and diversity of Mediterranean forest of Quercus pirenaica in relation to fire. For. Ecol. Manag. 2009, 257, 1596-1602. [CrossRef]

255. Gil-Tena, A.; Saura, S.; Brotons, L. Effects of forest composition and structure on bird species richness in a Mediterranean context: Implications for forest ecosystem management. For. Ecol. Manag. 2007, 242, 470-476. [CrossRef]

256. Hernando, S.; Brotons, L. Forest bird diversity in Mediterranean areas affected by wildfires: A multi-scale approach. Ecography 2002, 25, 161-172. [CrossRef] 
257. Gondard, H.; Romane, F.; Santa-Regina, I.; Leonardi, S. Forest management and plant species diversity in chesnut stands of three Mediterranean areas. Biodiver. Conserv. 2006, 15, 1129-1142. [CrossRef]

258. Buse, J.; Levanony, T.; Timm, A.; Dayan, T.; Assmann, T. Saproxylic beetle assemblages in the Mediterranean region: Impact of forest management on richness and structure. For. Ecol. Manag. 2010, 259, 1376-1384. [CrossRef]

259. Gil-Tena, A.; Fortin, M.J.; Brotons, L.; Saura, S. Forest avian species richness distribution and management guidelines under global change in Mediterranean landscapes. In Landscape Ecology in Forest Management and Conservation: Challenges and Solutions for Global Change; Li, C., Lafortezza, R., Chen, J., Eds.; Springer: Berlin, Germany, 2011; pp. 231-251.

260. Mazzei, A.; Bonacci, T.; Horak, J.; Brandmayr, P. The role of topography, stand and habitat features form management and biodiversity of a prominent forest hotspot of the Mediterranean Basin: Saproxylic beetles as possible indicators. For. Ecol. Manag. 2018, 410, 66-75. [CrossRef]

261. Carnicer, J.; Coll, M.; Pons, X.; Ninyerola, M.; Vayreda, J.; Peñuelas, J. Large-scale recruitment limitation in Mediterranean pines: The role of Quercus ilex and forest successional advance as key regional drivers. Glob. Ecol. Biogeogr. 2014, 23, 371-384. [CrossRef]

262. Carnicer, J.; Barbeta, A.; Sperlich, D.; Coll, A.; Peñuelas, J. Contrasting trait syndromes in angiosperms and conifers are associated with different responses of tree growth to temperature on a large scale. Front. Plant Sci. 2013, 4, 409. [CrossRef]

263. Puddu, G.; Falcucci, A.; Maiorano, L. Forest changes over a century in Sardinia: Implications for conservation in a Mediterranean hotspot. Agroforest. Syst. 2012, 85, 319-330. [CrossRef]

264. Cervera, T.; Pino, J.; Marull, J.; Padro, R.; Tello, E. Understanding the long-term dynamics of forest transition: From deforestation to afforestation in a Mediterranean landscape (Catalonia, 1868-2005). Land Use Pol. 2019, 80, 318-331. [CrossRef]

265. Carrascal, L.M.; Galvan, I.; Sanchez-Oliver, J.S.; Benayas, J.M.R. Regional distribution patterns predict bird occurrence in Mediterranean cropland afforestation. Ecol. Res. 2014, 29, 203-211. [CrossRef]

266. Tague, C.L.; Moritz, M.; Hanan, E. The changing water cycle: The eco-hydrologic impacts of forest density reduction in Mediterranean (seasonality dry) regions. Wiley Interdiscip. Rev. Water 2019, 6, 1350. [CrossRef]

267. Vacca, A. Effect of land use on forest floor and soil of a Quercus suber L-forest in Gallura (Sardinia, Italy). Land Degrad. Develop. 2000, 11, 167-180. [CrossRef]

268. Rosati, L.; Fipaldini, M.; Marignani, M.; Blasi, C. Effects of fragmentation on vascular plant diversity in a Mediterranean forest archipelago. Plant Biosys. 2010, 144, 38-46. [CrossRef]

269. Gonzalez-Moreno, P.; Quero, J.L.; Poorter, L.; Bonet, F.J.; Zamora, R. Is spatial structure the key to promote plant diversity in Mediterranean forest plantations? Basic Appl. Ecol. 2011, 12, 251-259. [CrossRef]

270. Velamazan, M.; San Miguel, A.; Escribano, R.; Perea, R. Compatibility of regeneration silviculture and wild ungulates in a Mediterranean pine forest: Implications for tree recruitment and Woody plant diversity. Ann. For. Sci. 2018, 75, 35. [CrossRef]

271. Malavasi, M.; Carranza, M.L.; Moravec, D.; Cutini, M. Reforestation dynamics after land abandonment: A trajectory analysis in Mediterranean mountain landscapes. Reg. Environ. Chang. 2018, 18, 2459-2469. [CrossRef]

272. Teruel-Coll, M.; Pareja, J.; Bartolome, J.; Serrano, E.; Mentaberre, G.; Cuenca, R. Effects of boom and bust grazing Management on vegetation and Health of beef cattle used for wildfire prevention in a Mediterranean forest. Sci. Total Environ. 2019, 665, 18-22. [CrossRef] [PubMed]

273. Ibañez, B.; Gomez-Aparicio, L.; Stoll, P.; Avila, J.M.; Perez-Ramos, I.M.; Maranon, T. A Neighborhood analysis of the consequences of Quercus suber decline for regeneration dynamics in Mediterranean forests. PLoS ONE 2015, 10, 0117827. [CrossRef] [PubMed]

274. De Dios, V.R.; Fischer, C.; Colinas, C. Climate change effects on Mediterranean forest and preventive measures. New For. 2007, 33, 29-40. [CrossRef]

275. Marañón-Jiménez, S.; Castro, J. Effect of decomposing post-fire coarse woody debris on soil fertility and nutrient availability in a Mediterranean ecosystem. Biogeochemistry 2013, 112, 519-535. [CrossRef]

276. Granados, M.E.; Vilagrosa, A.; Chirino, E.; Vallejo, V.R. Reforestation with resprouter species to increase diversity and resilence in Mediterranean pine forest. For. Ecol. Manag. 2016, 362, 231-240. [CrossRef]

277. Tomaz, C.; Alegria, C.; Monteiro, J.M.; Teixeira, M.C. Land cover change and afforestation of marginal and abandoned Agricultural land: A 10 year analysis in a Mediterranean region. For. Ecol. Manag. 2013, 308, 40-49. [CrossRef]

278. Cutino, I.; Pasta, S.; Maggiore, C.V.; Badalamenti, E.; La Mantia, T. The role of dominant tree cover and silvicultural practices on the post-fire recovery of Mediterranean afforestation. An. Silvic. Res. 2018, 42, 20-31.

279. Pausas, J.G.; Bladé, C.; Valdecantos, A.; Seva, J.P.; Fuentes, D.; Alloza, A.; Vilagrosa, A.; Bautista, S.; Cortina, J.; Vallejo, R. Pines and oaks in the restoration of Mediterranean landscape of Spain: New perspectives for an old practice-a review. Plant Ecol. 2004, 171, 209-220. [CrossRef]

280. Cuesta, B.; Benayas, J.M.R.; Gallardo, A.; Villar-Salvador, P.; Gonzalez-Espinosa, M. Soil Chemical properties in abandoned Mediterranean cropland after succession and oak reforestation. Acta Oecol. 2012, 38, 58-65. [CrossRef]

281. Andres, C.; Ojeda, F. Effects of afforestation with pines on Woody plant diversity of Mediterranean heathlands in southern Spain. Biodiv. Conserv. 2002, 11, 1511-1520. [CrossRef]

282. Maestre, F.T.; Cortina, J.; Bautista, S.; Bellot, J. Does Pinus halepensis facilitate the establishment of shrubs in Mediterranean semi-arid afforestation? For. Ecol. Manag. 2003, 176, 147-160. [CrossRef]

283. Bellot, J.; Maestre, F.T.; Chirino, E.; Hernandez, N.; de Urbina, J.O. Afforestation with Pinus halepensis reduces native shrub performance in a Mediterranean semiarid area. Acta Oecol. 2004, 25, 7-15. [CrossRef] 
284. Benayas, J.M.R.; Navarro, J.; Espigares, T.; Nicolau, J.M.; Zavala, M.A. Effects of artificial shading and weed mowing in reforestation of Mediterranean abandoned cropland with contrasting Quercus species. For Ecol. Manag. 2005, 212, 302-314. [CrossRef]

285. Castro, J.; Zamora, R.; Hodar, J.A.; Gomez, J.M.; Gomez-Aparicio, L. Benefits of using shrubs as nurse plants for a reforestation in Mediterranean mountains: A 4-year study. Restor. Ecol. 2004, 12, 352-358. [CrossRef]

286. Gasque, M.; Garcia-Fayos, P. Interaction between Stipa tenacissima and Pinus halepensis: Consequences for reforestation and the dynamics of grass steppes in semi-arid Mediterranean areas. For. Ecol. Manag. 2004, 189, 251-261. [CrossRef]

287. Osem, Y.; Ginsberg, P.; Tauber, I.; Atzmon, N.; Perevolotsky, A. Sustainable management of Mediterranean planted coniferous forest: An Israeli definition. J. For. 2008, 106, 38-46.

288. Osem, Y.; Lavi, A.; Rosenfeld, A. Colonization of Pinus halepensis in Mediterranean habitats: Consequences of afforestation, grazing and fire. Biol. Invasions 2011, 13, 485-498. [CrossRef]

289. Mauri, A.; Di Leo, M.; de Rigo, D.; Caudullo, G. Pinus halepensis and Pinus brutia in Europe: Distribution, habitat, usage and threats. In European Atlas of Forest Tree Species; San-Miguel-Ayanz, J., de Rigo, D., Caudullo, G., Houston Durrant, T., Mauri, A., Eds.; Publications Office of the EU: Luxembourg, 2016; p. e0166b8+.

290. Barbera, G.G.; Martinez-Fernandez, F.; Alvarez-Rogel, J.; Albadalejo, J.; Castillo, V. Short- and intermediate-term effects of site and plant preparation techniques on reforestation of a Mediterranean semiarid ecosystem with Pinus halepensis Mill. New For. 2005, 29, 177-198. [CrossRef]

291. Catarineu, C.; Reyes-López, J.; Herraiz, J.A.; Barberá, G.G. Effect of pine reforestation associated with soil disturbance on ant assemblages (Hymenoptera: Formicidae) in a semiarid steppe. Eur. J. Entomol. 2018, 115, 562-574. [CrossRef]

292. Kus, M.; Ulgen, H.; Gunes, Y.; Kiris, R.; Ozel, A.; Zeydanli, U. Carbon certification of afforestation and reforestation areas in Turkey. Carbon Management, Technologies, and Trends in Mediterranean Ecosystems. In Carbon Management, Technologies, and Trends in Mediterranean Ecosystems; Ersahin, S., Kapur, S., Akca, E., Namli, A., Erdogan, H.E., Eds.; Springer: Cham, Switzerland, 2017; Volume 15, pp. 131-137.

293. Querejeta, J.I.; Roldan, A.; Albadalejo, J.; Castillo, V. The role of mycorrhizae, site preparation, and organioc amendment in the afforestation of a semi-arid Mediterranean site with Pinus halepensis. For Sci. 1998, 44, 203-211.

294. Hueso-Gonzalez, P.; Martinez-Murillo, J.F.; Ruiz-Sinoga, J.D. The impact of organic emendments on forest soil properties under Mediterranean climatic conditions. Land Degrad. Develop. 2014, 25, 604-612. [CrossRef]

295. Jimenez-Gonzalez, M.A.; De la Rosa, J.M.; Jimenez-Morillo, N.T.; Almendros, G.; Gonzalez-Perez, J.A.; Knicker, H. Post-fire recovery of soil organic Matter in a Cambisol from typical Mediterranean forest in Southwestern Spain. Sci. Total Environ. 2016, 572, 1414-1421. [CrossRef]

296. Hueso-Gonzalez, P.; Martinez-Murillo, J.F.; Ruiz-Sinoga, J.D. Effects of topsoil treatments on afforestation in a dry Mediterranean climate (southern Spain). Solid Earth 2016, 7, 1479-1489. [CrossRef]

297. Coelho, C.O.A.; Ferreira, A.J.D.; Laouina, A.; Hamza, A.; Chaker, M.; Naafa, R.; Regaya, K.; Boule, A.K.; Keizer, J.J.; Carvalho, T.M.M. Changes in land use and land management practices affecting land degradation within forest and grazing ecosystems in the western Mediterranean. Adv. Geoecol. 2003, 37, 137-154.

298. Larcheveque, M.; Ballini, C.; Korboulewsky, N.; Montes, N. The use of compost in afforestation of Mediterranean areas: Effects of soil properties and young tree seedlings. Sci. Total Environ. 2006, 369, 220-230. [CrossRef]

299. Ingelmo, F.; Albiach, R.; Gamon, S. Organic matter of a soil amended with composted sludges and affected by simulated processes of soil degradation. Adv. Ecol. Sci. 2003, 18-19, 971-980.

300. Buendia, C.; Bussi, G.; Tuset, J.; Vericat, D.; Sabater, S.; Palau, A.; Batalla, R.J. Effects of afforestation on runoff and sediment load in an upland Mediterranean catchment. Sci. Total Environ. 2016, 540, 144-157. [CrossRef] [PubMed]

301. Lopez-Tirado, J.; Hidalgo, P.J. Ecological niche modelling of three Mediterranean pin especies in the South of Spain: A tool for afforestation/reforestation programs in the twenty-first century. New For. 2016, 47, 411-429. [CrossRef]

302. Campo, J.; Stijsiger, R.J.; Nadal-Romero, E.; Cammeraat, E.L.H. The effects of land abandonment and long-term afforestation practices on the organic carbon stock and lignin content of Mediterranean humid mountain Soils. Eur. J. Soil Sci. 2019, 70, 947-959. [CrossRef]

303. Riva, M.J.; Baeza, J.; Bautista, S.; Chrisoforou, M.; Daliakopoulos, I.N.; Hadjimitis, D.; Keizer, J.J.; Liniger, H.; Quaranta, G.; Ribeiro, C.; et al. How does land management contributr to the resilence of Mediterranean forest and rangelands? A participatory assessment. Land Degrad. Develop. 2018, 29, 3721-3735. [CrossRef]

304. Ruiz-Peinado, R.; Bravo-Oviedo, A.; Lopez-Senespleda, E.; Bravo, F.; del Rio, M. Forest Management and carbon sequestration in the Mediterranean region. A review. For. Syst. 2017, 26, eR04S. [CrossRef]

305. Mavsar, R.; Rois, M.; Palahi, M. Innovative and integrated approaches for improved of the Mediterranean forest ecosystem. Forest Policy and Economics in Support of Good Governance. Eur. Forest Inst. Proc. 2010, 58, 157-160.

306. Moya, D.; Alfaro-Sanchez, R.; Lopez-Serrano, F.; Dadi, T.; Hernandez-Tecles, E.; Ferrandis, P.; Heras, J.D.L. Post-fire Management of Mediterranean forests: Carbon storage in regenerated areas in Eastern iberian Peninsula. Cuad. Investig. Geogr. 2014, 40, 371-386. [CrossRef]

307. Garcia-Orenes, F.; Arcenegui, V.; Chrenkova, K.; Mataix-Solera, J.; Molto, J.; Jara-Navarro, A.B.; Torres, M.P. Effects of salvage logging on soil properties and vegetation recovery in a fire-affected Mediterranean forest: A two year monitoring research. Sci. Total Environ. 2017, 586, 1057-1065. [CrossRef] 
308. Herrando, S.; Brotons, L.; Guallar, S.; Sales, S.; Pons, P. Postfire forest management and Mediterranean birds: The importance of the logging remmants. Biodiv. Conser. 2009, 18, 2153-2164. [CrossRef]

309. Barberis, A.; Dettori, S.; Filigheddu, M.R. Management problems in Mediterranean cork oak forest: Post-fire recovery. J. Arid Environ. 2003, 54, 565-569. [CrossRef]

310. Koufopoulou, S.; Michalopoulus, C.; Pappa, A.; Tzamtzis, N. Impact of a long-term fire retardant (Fire troll 931) on the physicchemical properties of leachates from a Mediterranean forest soil: A short term, lab-scale study. Water Air Soil Pollut. 2015, 226, 158. [CrossRef]

311. Sabbi, A.; Salvati, L. Searching for a downward spiral? Soil erosion risk, agro-forest landscape and socioeconomic conditions in Italian local communities. Land Use Pol. 2014, 41, 388-396. [CrossRef]

312. Fabbio, G.; Merlo, M.; Tosi, V. Silvicultural Management in maintaining biodiversity and resistance of forest in Europe-The Mediterranean región. J. Environ. Manag. 2003, 67, 67-76. [CrossRef]

313. Zornoza, R.; Mataix-Solera, J.; Guerrero, C.; Arcenegui, V.; Mataix-Beneyto, J.; Gomez, I. Validation the effectiveness and sensitivity of two soil Quality índices base don natural forest Soils under Mediterranean conditions. Soil Biol. Biochem. 2008, 40, 2079-2087. [CrossRef]

314. Llovet, J.; Ruiz-Valera, M.; Josa, R.; Vallejo, V.R. Soil responses to fire in Mediterranean forest landscapes in relation to the previous stage of land abandonment. Int. J. Wildland Fire 2009, 18, 222-232. [CrossRef]

315. Novara, A.; Gristina, L.; Sala, G.; Galati, A.; Crescimanno, M.; Cerdà, A.; Badalamenti, E.; La Mantia, T. Agricultural land abandonment in Mediterranean Environment provides ecosystem services via soil carbón sequestration. Sci. Total Environ. 2017, 576, 420-429. [CrossRef] [PubMed] 